\title{
Novel Diamide-Based Benzenesulfonamides as Selective Carbonic Anhydrase IX Inhibitors Endowed with Antitumor Activity: Synthesis, Biological Evaluation and In Silico Insights
}

\author{
Mohamed A. Abdelrahman ${ }^{1}$, Wagdy M. Eldehna ${ }^{2, *}$, Alessio Nocentini ${ }^{3,4}$, Silvia Bua ${ }^{3}{ }^{\mathbb{C}}$, \\ Sara T. Al-Rashood ${ }^{5}$, Ghada S. Hassan ${ }^{6}$ (D), Alessandro Bonardi ${ }^{3,4}$, \\ Abdulrahman A. Almehizia ${ }^{5}$ (D) Hamad M. Alkahtani ${ }^{5}$, Amal Alharbi ${ }^{5}$, Paola Gratteri ${ }^{4}$ and \\ Claudiu T. Supuran ${ }^{3, *(D)}$ \\ 1 Department of Pharmaceutical Chemistry, Faculty of Pharmacy, Egyptian Russian University, Badr City, \\ Cairo 11829, Egypt; mohamed.ashraf.eru@gmail.com \\ 2 Department of Pharmaceutical Chemistry, Faculty of Pharmacy, Kafrelsheikh University, Kafrelsheikh 33516, \\ Egypt \\ 3 Department of NEUROFARBA, Section of Pharmaceutical and Nutraceutical Sciences, University of \\ Florence, Polo Scientifico, Via U. Schiff 6, Sesto Fiorentino, 50019 Firenze, Italy; \\ alessio.nocentini@unifi.it (A.N.); silvia.bua@unifi.it (S.B.); alessandro.bonardi@unifi.it (A.B.) \\ 4 Department of NEUROFARBA, Section of Pharmaceutical and Nutraceutical Sciences, Laboratory of \\ Molecular Modeling Cheminformatics \& QSAR, University of Florence, Polo Scientifico, Via U. Schiff 6, Sesto \\ Fiorentino, 50019 Firenze, Italy; paola.gratteri@unifi.it \\ 5 Department of Pharmaceutical Chemistry, College of Pharmacy, King Saud University, P.O. Box 2457, Riyadh \\ 11451, Saudi Arabia; salrashood@ksu.edu.sa (S.T.A.-R.); mehizia@ksu.edu.sa (A.A.A.); \\ haalkahtani@ksu.edu.sa (H.M.A.); amal.harbi@gmail.com (A.A.) \\ 6 Department of Medicinal Chemistry, Faculty of Pharmacy, Mansoura University, Mansoura 35516, Egypt; \\ ghadak25@yahoo.com \\ * Correspondence: wagdy2000@gmail.com (W.M.E.); claudiu.supuran@unifi.it (C.T.S.)
}

Received: 29 April 2019; Accepted: 17 May 2019; Published: 20 May 2019

\begin{abstract}
In this work, we present the synthesis and biological evaluation of novel series of diamide-based benzenesulfonamides $5 \mathrm{a}-\mathrm{h}$ as inhibitors of the metalloenzyme carbonic anhydrase (CA, EC 4.2.1.1) isoforms hCA I, II, IX and XII. The target tumor-associated isoforms hCA IX and XII were undeniably the most affected ones ( $K_{\mathrm{I}} \mathrm{S}$ : 8.3-123.3 and 9.8-134.5 nM, respectively). Notably, diamides $5 \mathrm{a}$ and $5 \mathrm{~h}$ stood out as a single-digit nanomolar hCA IX inhibitors $\left(K_{\mathrm{I}} \mathrm{s}=8.8\right.$ and $\left.8.3 \mathrm{nM}\right)$. The SAR outcomes highlighted that bioisosteric replacement of the benzylidene moiety, compounds $5 \mathrm{a}-\mathrm{g}$, with the hetero 2-furylidene moiety, compound $5 \mathrm{~h}$, achieved the best IX/I and IX/II selectivity herein reported with SIs of 985 and 13.8, respectively. Molecular docking simulations of the prepared diamides within CA IX active site revealed the ability of $5 \mathrm{~h}$ to establish an additional H-bond between the heterocyclic oxygen and HE/Gln67. Moreover, benzenesulfonamides 5a, 5b and 5h were evaluated for their antitumor activity against renal cancer UO-31 cell line. Compound $5 \mathrm{~h}$ was the most potent derivative with about 1.5-fold more enhanced activity $\left(\mathrm{IC}_{50}=4.89 \pm 0.22 \mu \mathrm{M}\right)$ than the reference drug Staurosporine $\left(\mathrm{IC}_{50}=7.25 \pm 0.43 \mu \mathrm{M}\right)$. Moreover, $5 \mathrm{a}$ and $5 \mathrm{~h}$ were able to induce apoptosis in UO-31 cells as evidenced by the significant increase in the percent of annexinV-FITC positive apoptotic cells by 22.5 - and 26.5-folds, respectively.
\end{abstract}

Keywords: anticancer activity; diamide-based benzenesulfonamides; molecular docking; selective hCAIX inhibitors; synthesis 


\section{Introduction}

Carbonic anhydrases (CA) are zinc metalloenzymes that play a pivotal role in most living organisms catalyzing the interconversion of carbon dioxide and water to bicarbonate and protons [1]. Seven distinct CA families $\left(\alpha-, \beta-, \gamma_{-}, \delta_{-}, \zeta_{-}, \eta-\right.$ and $\left.\theta-C A s\right)$ are known to date $[1,2]$. Human encode 15 different $\alpha$-CA isoforms among which some are cytosolic (CA I, CA II, CA III, CA VII and CA XIII), others are membrane bound (CA IV, CA IX, CA XII, CA XIV and CA XV), two of them are mitochondrial (CA VA and CA VB), and one isozyme is secreted in saliva (CA VI) [2]. They are involved in numerous physiological and pathological processes such as gluconeogenesis, lipogenesis, ureagenesis and tumorigenicity [2]. While inhibitors targeting hCA I are useful in retinal and cerebral edema, inhibitors targeting hCA II are used as diuretics, in the management of edema, as antiglaucoma agents, antiepileptic drugs, and also for the treatment of altitude sickness [1,2].

The hCA IX expression is usually induced by hypoxia in certain types of solid tumors, such as glioma, breast cancer and colon carcinoma [3,4]. Besides, inhibition of hCA IX was strongly associated with remarkable suppression of the growth of both primary tumor stages as well as metastases which makes the enzyme a validated target for the treatment of diverse cancers [5]. Accordingly, discovery of isoform hCA IX selective inhibitors stands out as a crucial step to establish a promising cancer therapy devoid of the classical adverse effects owing to isoforms hCA I and II inhibition.

While different CA inhibition mechanisms are known, the zinc binder sulfonamides undoubtedly represent the most important class, with many derivatives in clinical use for decades or clinical development in the last period, such as SLC-0111 (Figure 1) [6]. The CA inhibition mechanism with sulfonamides is mainly mediated by coordination of its deprotonated form $\left(\mathrm{SO}_{2} \mathrm{NH}^{-}\right)$to the positively charged $\mathrm{Zn}$ (II) ion from the enzyme active site. Moreover, the sulfonamide moiety engages two $\mathrm{H}$-bonds: the $\mathrm{NH}^{-}$group acts as donor, while the $\mathrm{S}=\mathrm{O}$ as acceptor with T199 OG1 atom and backbone $\mathrm{NH}$ respectively. These binding features are common among the active site architectures for all the $\alpha$-class fifteen human isozymes.<smiles>NS(=O)(=O)c1ccc(NC(=O)Nc2ccc(NC(=O)Nc3nnc(-c4ccc(Cl)cc4)s3)cc2)cc1</smiles>
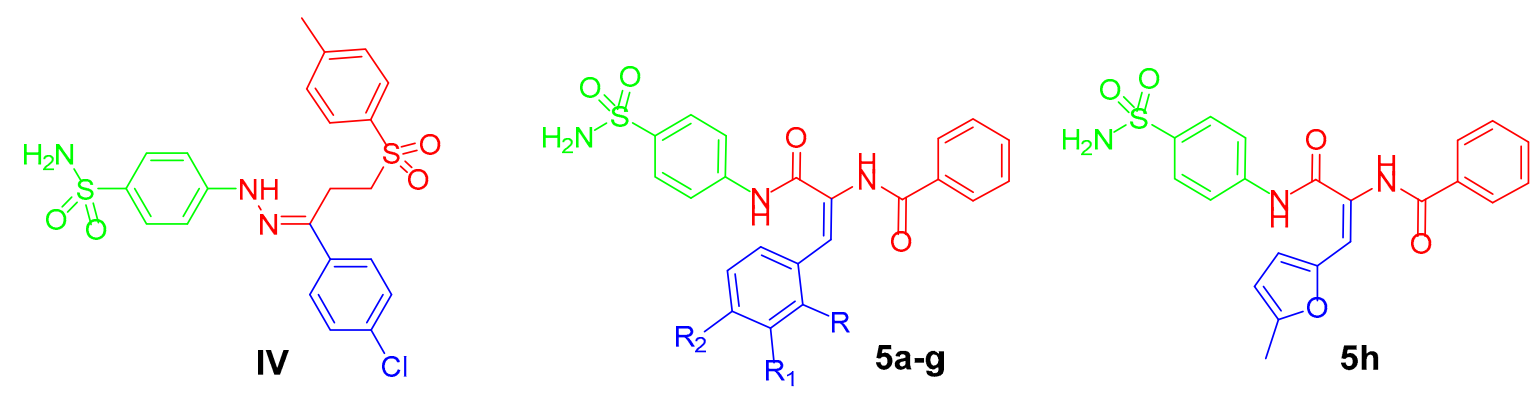

Figure 1. Structures of some reported benzenesulfonamides-based CAIs (I-IV) and the target compounds (5a-g and $5 \mathbf{h})$.

Several approaches have been adopted for obtaining isoform-selective CAIs, with the "tail approach" being the most successful and exploited one (Figure 1) [7-9]. It consists in appending "tails", with a diverse chemical nature, to the aromatic/heterocyclic ring possessing the zinc binding sulfonamide group, in order to interact with amino acid residues from the middle and the rim parts of the active site cavity. In this context, several sulfonamide-based derivatives were successfully developed as isoform hCA IX selective inhibitors through utilization of "tail approach" (compounds Figure 1II-IV) [7-9]. 
Pursuing on our effort towards development of selective hCA IX inhibitors [10-13], herein we present the synthesis, and biological evaluation of novel series of diamide-based benzenesulfonamides $5 \mathrm{a}-\mathrm{h}$. The herein reported diamides possess a zinc anchoring moiety of the benzenesulfonamide type that was linked to benzylidene tails incorporating halogen, methyl or methoxy substituents to ensure suited SAR exploration regarding the hydrophobic region of the binding cleft. Also, the bioisosteric replacement approach was adopted to replace the benzylidene tails (compounds 5a-g) with the hetero 2-furylidene one (compound 5h, Figure 1). The amide functionality of the appended benzamide moiety was expected to engage contact with the amino acids residues of the "hydrophilic" region of the active site.

All the newly-synthesized diamides $5 \mathrm{a}-\mathrm{h}$ were characterized and biologically tested against a panel of hCA I, II, IX and XII isoforms, using stopped-flow $\mathrm{CO}_{2}$ hydrase assay. Moreover, diamides $5 \mathrm{a}, 5 \mathrm{~b}$ and $5 \mathrm{~h}$ were evaluated for their anti-proliferative activity against renal cancer UO-31 cell line. Compound $5 \mathrm{~h}$ was further investigated for its apoptosis induction potential in UO-31 cells. Furthermore, molecular docking investigations were carried out to provide insights for the binding interactions of the herein reported benzenesulfonamides within hCA isozymes II and IX.

\section{Results and Discussion}

\subsection{Chemistry}

The synthetic pathway adopted for the preparation of the target diamide-based benzenesulfonamides $5 \mathrm{a}-\mathrm{h}$ was depicted in Scheme 1. The azlactone intermediates 3a-h were prepared by the ErlenmeyerPlöchl synthesis $[14,15]$ through reaction of hippuric acid 1 with different benzaldehyde derivatives $2 \mathrm{a}-\mathrm{g}$ or 5-methylfurfural $2 \mathrm{~h}$ in acetic anhydride in the presence of Hünig's base [16]. Then, the target diamide-based benzenesulfonamides $5 \mathrm{a}-\mathrm{h}$ were obtained via reaction of azlactone intermediates $3 \mathrm{a}-\mathrm{h}$ with $p$-aminobenzenesulfonamide 4 in glacial acetic acid in the presence of sodium acetate to afford the corresponding target benzenesulfonamides $5 \mathrm{a}-\mathrm{h}$ with $80-93 \%$ yield (Scheme 1 ).

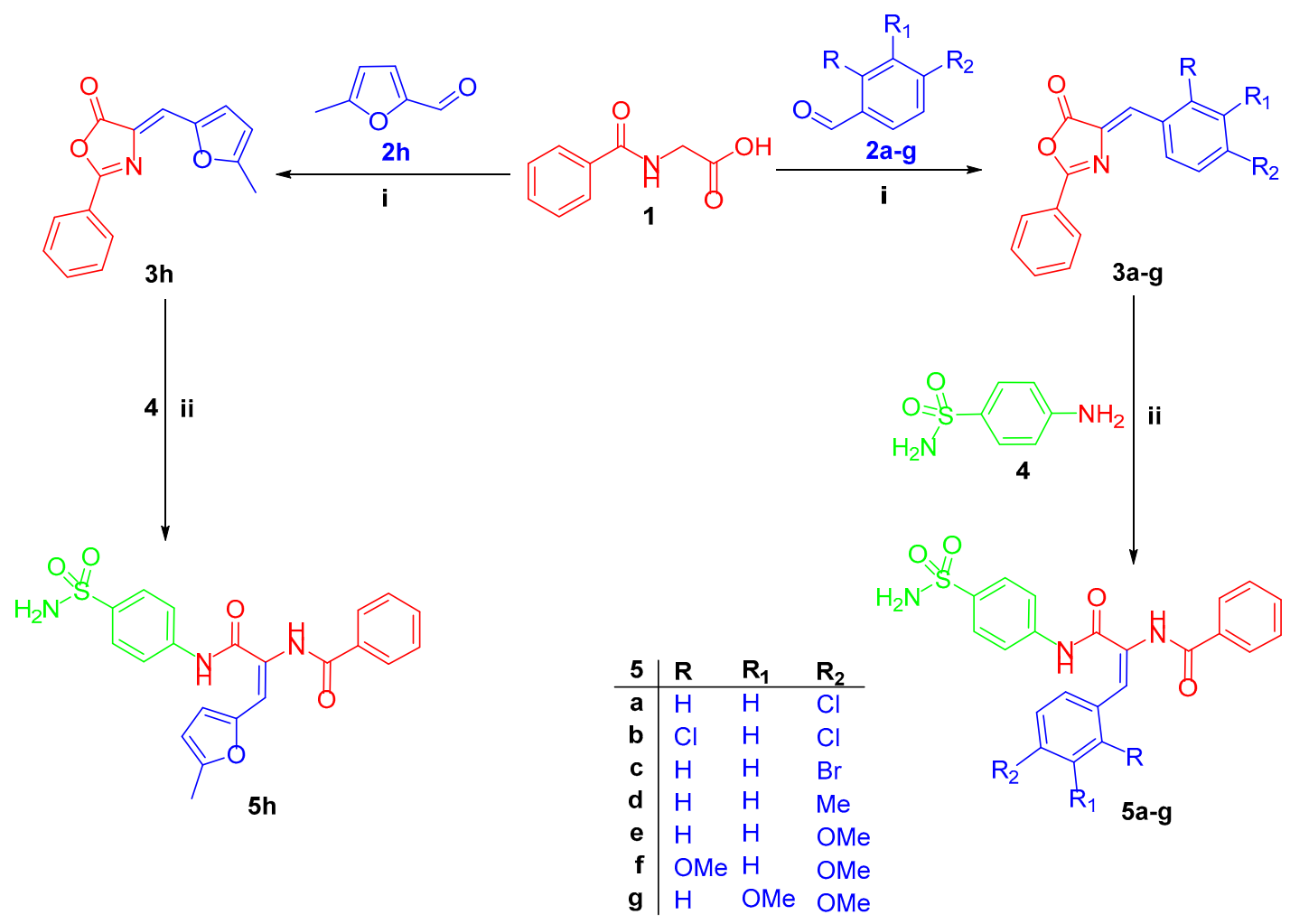

Scheme 1. Synthesis of diamide-based benzenesulfonamides 5a-h; Reagents and conditions: (i) Acetic anhydride/Hünig's base/reflux 3 hrs., (ii) Glacial acetic acid/ $\mathrm{CH}_{3} \mathrm{COONa} / \mathrm{reflux} 4 \mathrm{~h}$. 
The elemental and spectral data supported the structures of the target benzenesulfonamides $5 a-h$. IR spectra of $5 a-h$ revealed the presence of bands for $\left(\mathrm{NH}_{2}\right)$ group at $3316-3249 \mathrm{~cm}^{-1}$, and bands of $(\mathrm{C}=\mathrm{O})$ group around $1629-1636 \mathrm{~cm}^{-1}$. Also, their IR spectra displayed two bands of $\left(\mathrm{SO}_{2}\right)$ at (1350-1358) and (1157-1168) $\mathrm{cm}^{-1}$. Furthermore, the ${ }^{1} \mathrm{H}$ NMR spectra of benzenesulfonamides 5a-h displayed singlet signal of $\mathrm{D}_{2} \mathrm{O}$ exchangeable $\mathrm{NH}_{2}$ protons of salfamoyl group at $\delta$ 7.25-7.49 ppm. In addition to presence of olifenic signal at $\delta 7.04-7.32 \mathrm{ppm}$, and two $\mathrm{D}_{2} \mathrm{O}$ exchangeable NH protons at $\delta$ 9.85-10.16 ppm and $\delta 10.23-10.65 \mathrm{ppm}$. On the other hand, compounds $5 \mathrm{~d}-\mathrm{g}$ were confirmed by presence of aliphatic signals of; $\mathrm{CH}_{3}$ protons at $\delta 2.28-2.36 p p m$ for $5 \mathrm{~d}, \mathrm{OCH}_{3}$ protons at $\delta 3.74-3.83 p p m$ for $5 \mathrm{e}-\mathrm{g}$. Moreover, ${ }^{13} \mathrm{C}$ NMR spectra of compounds $5 \mathrm{a}-\mathrm{h}$ displayed two signals for $\mathrm{C}=\mathrm{O}$ groups at $\delta$ 164.52-169.74 ppm, also, ${ }^{13} \mathrm{C}$ NMR spectra for $5 \mathrm{~d}-\mathrm{g}$ displayed the aliphatic signals of $\mathrm{CH}_{3}$ at $\delta$ 21.38-21.75 ppm for $5 \mathrm{~d}$, and $\mathrm{OCH}_{3}$ at $\delta 55.52-56.11 \mathrm{ppm}$ for $5 \mathrm{f}$ and $5 \mathrm{~g}$.

\subsection{Biological Evaluation}

\subsubsection{Carbonic Anhydrase Inhibition}

The CA inhibitory activity of all the newly prepared diamide-based benzenesulfonamides $5 a-h$ was evaluated towards the cytosolic isoforms hCA I and II, as well as towards the transmembrane tumor-associated isoforms hCA IX and XII using an applied photophysics stopped-flow instrument for assaying the $\mathrm{CA}$-catalyzed $\mathrm{CO}_{2}$ hydration activity [17]. The inhibitory activities were compared to acetazolamide (AAZ), a clinically used standard CA inhibitor. The following SAR could be derived from the results in Table 1:

Table 1. Inhibition data of human CA isoforms hCA I, II, IX and XII for diamide-based benzenesulfonamides $5 \mathrm{a}-\mathrm{h}$, determined by stopped-flow $\mathrm{CO}_{2}$ hydrase assay, using acetazolamide (AAZ) as a standard drug.

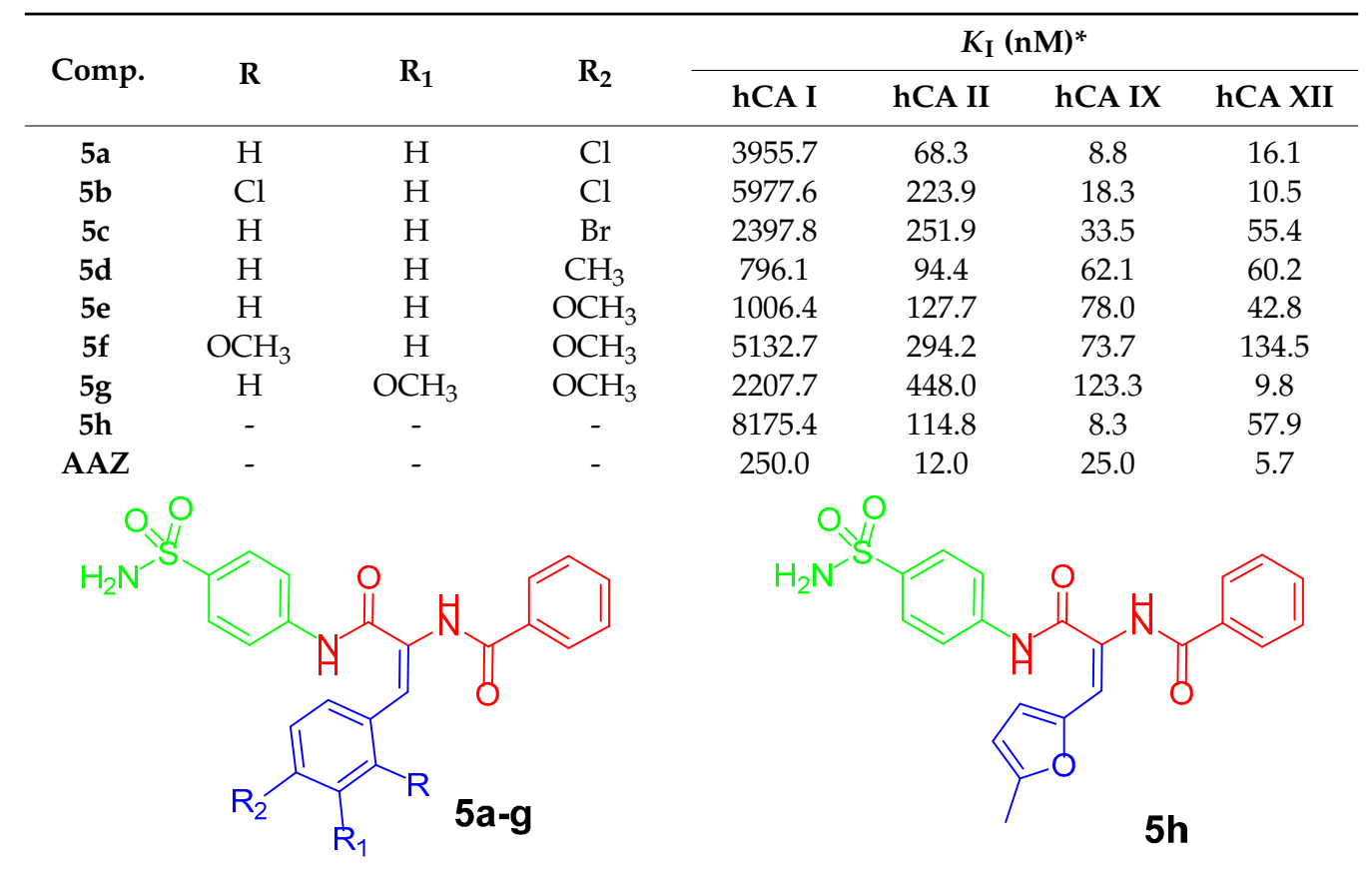

\footnotetext{
* Mean from 3 different assays, by a stopped flow technique (errors were in the range of $\pm 5-10 \%$ of the
} reported values).

(i) The cytosolic isoform hCA I was weekly inhibited by most of the diamide-based benzenesulfonamides $5 \mathrm{a}-\mathrm{h}$ with inhibition constants $\left(K_{\mathrm{I}} \mathrm{s}\right)$ in the micromolar range, in detail, between 1.006 and $8.175 \mu \mathrm{M}$, except for the $p$-tolyl analogue $5 \mathrm{~d}$ which arose as a nanomolar hCA I inhibitor with a $K_{\mathrm{I}}$ equals $796.1 \mathrm{nM}$, that represents 3-fold decreased activity to the reference drug $\mathrm{AAZ}\left(K_{\mathrm{I}}=250 \mathrm{nM}\right)$. 
(ii) The physiologically dominant isoform hCA II was moderately inhibited by the target diamides 5a-h with $K_{\mathrm{I}} \mathrm{s}$ spanning in the nanomolar range: $68.3-448 \mathrm{nM}$, Table 1 . The SAR outcomes hinted that mono substitution of the benzylidene moiety with $4-\mathrm{Cl}$ or $4-\mathrm{CH}_{3}$ substituents (compounds 5a and $5 \mathrm{~d} ; K_{\mathrm{I}} \mathrm{s}=68.3$ and $94.4 \mathrm{nM}$, respectively) is more beneficial for the activity against hCA II than di-substitution with $\mathrm{Cl}$ or $\mathrm{OCH}_{3}$ substituents (compounds 5b, 5f and 5g; $K_{\mathrm{I}} \mathrm{s}=223.9,294.2$ and 448.0 nM, respectively).

(iii) The target tumor-associated isoform hCA IX was efficiently inhibited by the prepared diamide-based benzenesulfonamides $5 \mathrm{a}-\mathrm{h}$ ( $K_{\mathrm{I}}$ values ranging between 8.3 and $78 \mathrm{nM}$, Table 1$)$, apart from the 3,4-( $\left(\mathrm{OCH}_{3}\right)_{2}$ benzylidene-bearing sulfonamide $5 \mathrm{~g}$, which possessed a slightly reduced inhibitory activity $\left(K_{\mathrm{I}}=123.3 \mathrm{nM}\right)$. Notably, diamides 5 a and $5 \mathrm{~h}$ stood out as a single-digit nanomolar hCA IX inhibitors with $K_{\mathrm{I}}$ values $=8.8$ and $8.3 \mathrm{nM}$, respectively, which are about three times more potent than the standard drug AAZ $\left(K_{\mathrm{I}}=25 \mathrm{nM}\right)$. Besides, diamide $5 \mathrm{~b}\left(K_{\mathrm{I}}=18.3 \mathrm{nM}\right)$ was 1.4 times more active than AAZ.

Regarding the impact of substitution of the benzylidene moiety, the hCA IX inhibitory activities were decreased in the following order: $4-\mathrm{Cl}>2,4-(\mathrm{Cl})_{2}>4-\mathrm{Br}>4-\mathrm{CH}_{3}>2,4-\left(\mathrm{OCH}_{3}\right)_{2}>4-\mathrm{OCH}_{3}$ $>3,4-\left(\mathrm{OCH}_{3}\right)_{2}$. This order of activity highlighted that incorporation of the electron-withdrawing halogens (compounds 5a-c; $K_{\mathrm{I}} \mathrm{s}: 8.8-33.5 \mathrm{nM}$ ) is more advantageous for the inhibitory activity toward hCA IX than the electron-donating methyl or methoxy groups (compounds $5 \mathrm{~d}-\mathrm{g} ; K_{\mathrm{I}} \mathrm{s}: 62.1-123.3 \mathrm{nM}$ ).

It is noteworthy that bioisosteric replacement of the substituted benzylidene moiety (compounds $5 \mathrm{a}-\mathrm{g} ; K_{\mathrm{I}} \mathrm{s}: 8.8-123.3 \mathrm{nM}$ ) with a hetero 2-furylidene moiety (compound $5 \mathrm{~h} ; K_{\mathrm{I}}=8.3 \mathrm{nM}$ ) resulted in a 1.1-fold to 14.9-fold efficacy enhancement, which could be attributed to an extra hydrogen bonding within the active site through the heterocyclic oxygen atom.

(iv) The data displayed in Table 1 ascribed to the prepared diamide-based benzenesulfonamides good efficacy in inhibiting the transmembrane tumor-associated isoform hCA XII. The inhibition profiles were found to be rather flat, since the measured $K_{\mathrm{I}} \mathrm{s}$ ranged between 9.8 and $60.2 \mathrm{nM}$, aside from diamide $5 \mathrm{f}$ whose efficacy raised to slightly higher concentration $\left(K_{\mathrm{I}}=134.5 \mathrm{nM}\right)$. In particular, diamide $5 \mathrm{~g}$ was emerged as the only single-digit nanomolar hCA XII inhibitor in this study $\left(K_{\mathrm{I}}=\right.$ $9.8 \mathrm{nM})$.

Concerning the effect of substitution of the benzylidene moiety, the hCA XII inhibitory activities were decreased in the order of: 3,4- $\left(\mathrm{OCH}_{3}\right)_{2}>2,4-(\mathrm{Cl})_{2}>4-\mathrm{Cl}>4-\mathrm{OCH}_{3}>4-\mathrm{Br}>4-\mathrm{CH}_{3}>2,4-\left(\mathrm{OCH}_{3}\right)_{2}$. It is worth stressing that, that bioisosteric replacement of the substituted benzylidene moiety with the 2-furylidene moiety elicited a worsening of effectiveness against hCA XII, unlike arose for hCA IX.

(v) Exploration of the the CA inhibitory trends in Table 1 revealed that all the examined diamide-based benzenesulfonamides $5 \mathrm{a}-\mathrm{h}$ displayed interesting selectivity towards hCA IX over hCA I spanning in the range 12.8-985 (Table 2). Also, the examined diamides possessed good hCA IX/II selectivity indexes spanning in the range 3.6-13.8, apart from diamides $5 \mathrm{~d}$ and $5 \mathrm{e}$ which displayed modest selectivity (SI $=1.4$ and 1.5 , respectively).

Table 2. Selectivity ratios for the inhibition of hCA IX and XII over hCA I and II for diamide-based benzenesulfonamides $5 \mathrm{a}-\mathrm{h}$ and acetazolamide.

\begin{tabular}{ccccc}
\hline Cmpd & I/IX & II/IX & I/XII & II/XII \\
\hline $5 \mathrm{a}$ & 449.5 & 7.8 & 245.7 & 4.2 \\
$5 \mathrm{~b}$ & 326.6 & 12.2 & 569.2 & 21.3 \\
$5 \mathrm{c}$ & 71.6 & 7.5 & 43.3 & 4.5 \\
$5 \mathrm{~d}$ & 12.8 & 1.5 & 13.2 & 1.7 \\
$5 \mathrm{e}$ & 12.9 & 1.4 & 23.5 & 3 \\
$5 \mathrm{f}$ & 69.9 & 4 & 38.2 & 2.2 \\
$5 \mathrm{~g}$ & 17.9 & 3.6 & 225.3 & 45.7 \\
$5 \mathrm{~h}$ & 985 & 13.8 & 141.2 & 2 \\
AAZ & 10.0 & 0.5 & 43.9 & 2.2 \\
\hline
\end{tabular}


Indeed, it is worth highlighting that bioisosteric replacement of the benzylidene moiety with the hetero 2-furylidene moiety, compound $5 \mathrm{~h}$, achieved the best IX/I and IX/II selectivity herein reported with SIs of 985 and 13.8, respectively.

\subsubsection{Antitumor Activity}

\section{Antitumor Activity towards 60 Cancer Cell Lines (NCI, USA)}

First, all diamide-based benzenesulfonamides herein reported $5 \mathrm{a}-\mathrm{h}$ were screened for their antitumor activity at one dose $\left(10^{-5} \mathrm{M}\right)$ assay against a panel of sixty cancer cell lines through the National Cancer Institute (NCI) Developmental Therapeutic Program (www.dtp.nci.nih.gov), according to US-NCI protocol. The cell growth and cell viability were evaluated using the sulforhodamine $B$ (SRB) colorimetric assay [18-20].

The obtained data were reported as mean-graph of the percentage growth of the different treated tumour cells (Supplementary Materials). Exploration of results for this assay confirmed that the examined diamide-based benzenesulfonamides $5 \mathrm{a}-\mathrm{h}$ had non-significant activity towards most NCI cancer cell lines. Of particular interest, all the prepared diamides displayed interesting selectivity towards renal cancer UO-31 cell line with percentage growth inhibition (GI\%) range of 13-35\% (Figure 2). Compound $5 \mathrm{~h}$ was found to be the most potent member against UO-31 cells, in this assay, with GI\% equals 35 .

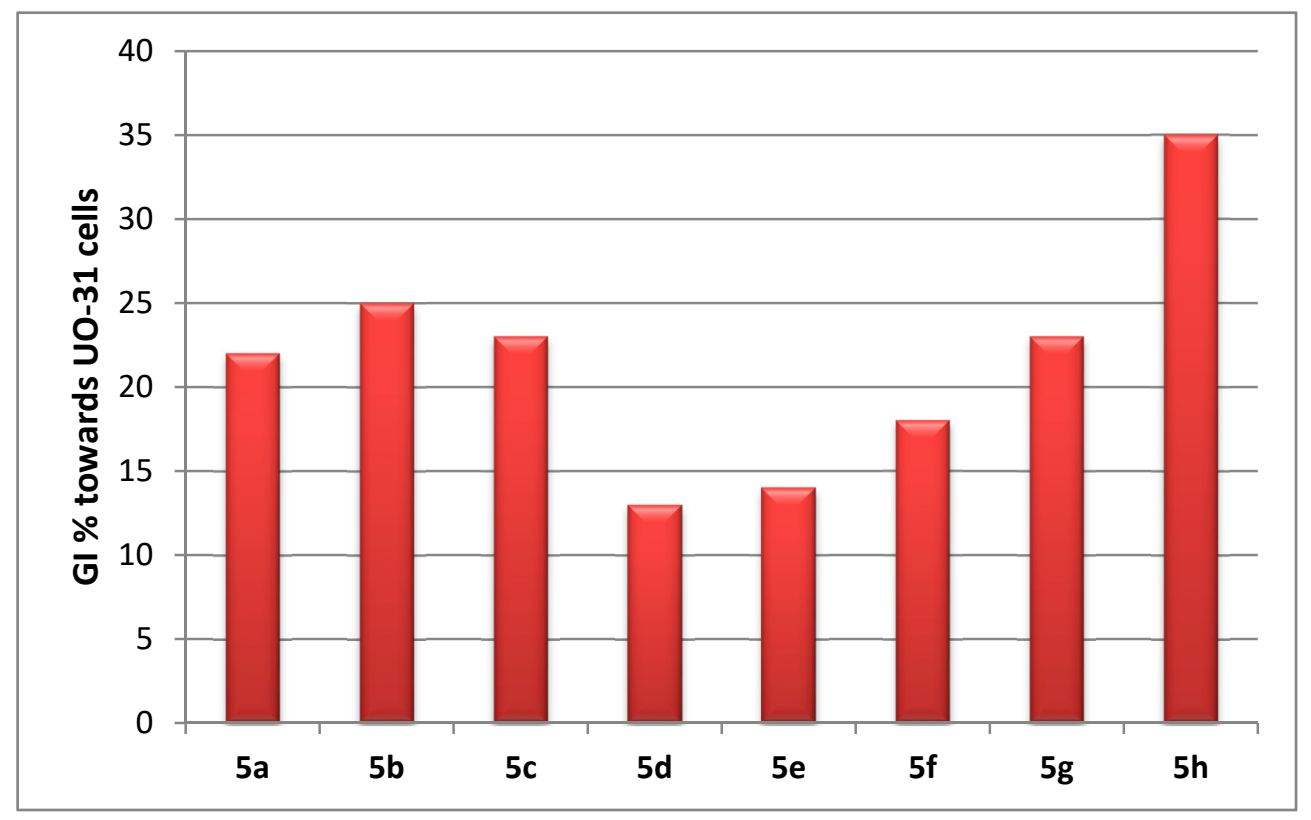

Figure 2. Percentage growth inhibition (GI\%) for the target diamide-based benzenesulfonamides $\mathbf{5 a}-\mathbf{h}$ towards the renal cancer UO-31 cell line.

Anti-Proliferative Activity towards Renal Cancer UO-31 Cell Line

As diamide-based benzenesulfonamides $5 \mathrm{a}, 5 \mathrm{~b}$ and $5 \mathrm{~h}$ emerged as low-nanomolar hCA IX inhibitors ( $K_{\mathrm{I}} \mathrm{s}$ : of $8.3-18.3 \mathrm{nM}$ ) with good hCA IX/I and IX/II selectivity (SI: 326.6-985 and 7.8-13.8, respectively), they were selected to be evaluated for their antitumor activity against renal cancer UO-31 cell line, using the protocol of MTT colorimetric assay as reported by T. Mosmann [21]. Staurosporine was adopted in the experiment as a reference anticancer drug. The results are presented as $\mathrm{IC}_{50}$ values and displayed in Table 3. 
Table 3. In vitro anti-proliferative activity of diamide-based benzenesulfonamides $5 \mathrm{a}, 5 \mathrm{~b}$ and $5 \mathrm{~h}$ against renal UO-31 cancer cell line.

\begin{tabular}{cc}
\hline \multirow{2}{*}{ Compound } & $\mathrm{IC}_{\mathbf{5 0}}(\boldsymbol{\mu M})^{\mathbf{a}}$ \\
\cline { 2 - 2 } & UO-31 \\
\hline $5 a$ & $6.53 \pm 0.38$ \\
$5 b$ & $16.68 \pm 0.92$ \\
$5 \mathrm{~h}$ & $4.89 \pm 0.22$ \\
Staurosporine & $7.25 \pm 0.43$ \\
\hline lues are the mean \pm S.D. of three separate experiments.
\end{tabular}

The results for the MTT assay presented in Table 3 revealed that that the examined diamides possessed good anti-proliferative activity towards UO-31 cell line ( $\mathrm{IC}_{50}$ range: $4.89 \pm 0.22-16.68 \pm$ $0.92 \mu \mathrm{M})$. Notably, diamide-based sulfonamide $5 \mathrm{~h}$ was the most potent derivative with about 1.5-fold more enhanced activity $\left(\mathrm{IC}_{50}=4.89 \pm 0.22 \mu \mathrm{M}\right)$ than the reference drug Staurosporine $\left(\mathrm{IC}_{50}=7.25 \pm\right.$ $0.43 \mu \mathrm{M})$. Also, compound 5a showed comparable activity $\left(\mathrm{IC}_{50}=6.53 \pm 0.38 \mu \mathrm{M}\right)$ to the reference drug Staurosporine.

\section{Cell Cycle Analysis}

The effect of diamide-based benzenesulfonamides $5 \mathrm{a}$ and $5 \mathrm{~h}$ on cell cycle progression was examined in renal UO-31 cancer cells, through a DNA flow cytometric assay (Figure 3). The UO-31 cells were treated with diamides $5 \mathrm{a}$ and $5 \mathrm{~h}$ at their $\mathrm{IC}_{50}$ concentrations $\left(\mathrm{IC}_{50}=6.53 \pm 0.38\right.$ and $4.89 \pm$ $0.22 \mu \mathrm{M})$ for $24 \mathrm{~h}$.

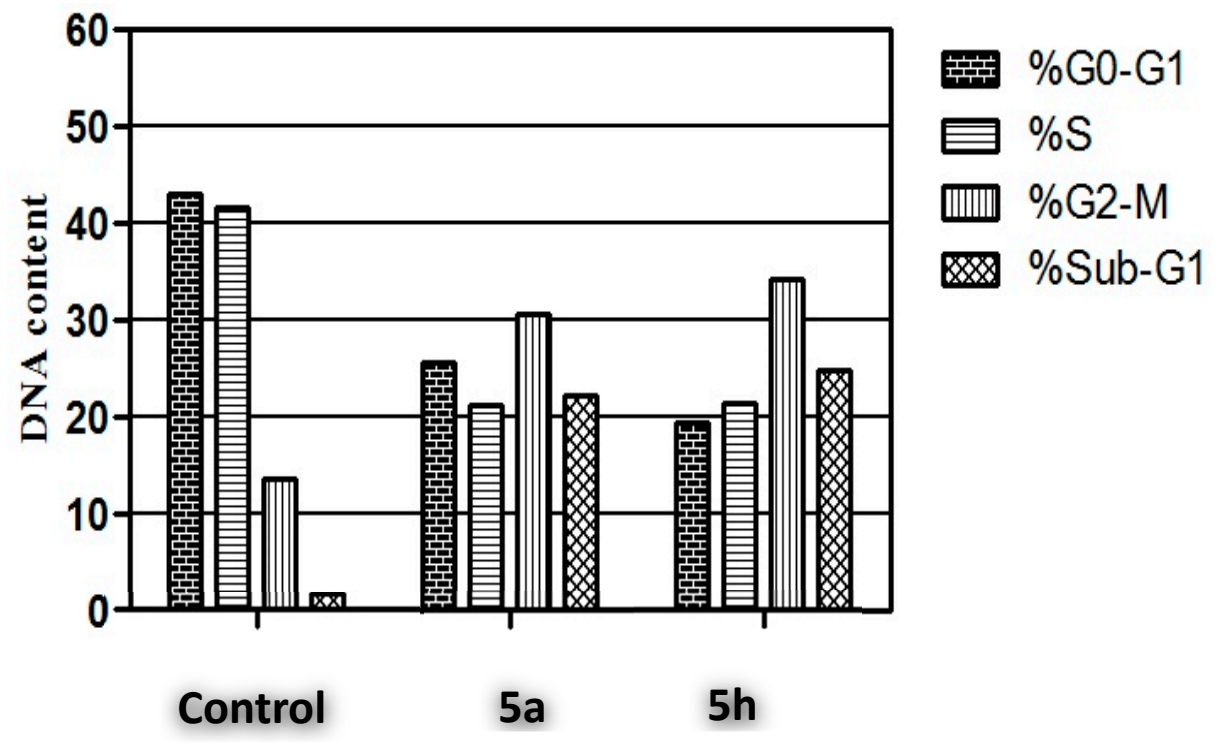

Figure 3. Effect of diamide-based benzenesulfonamides $5 \mathrm{a}$ and $5 \mathrm{~h}$ on the phases of cell cycle of UO-31 cells.

The outcomes of this flow cytometric assay (Figure 3) suggested that exposure of renal UO-31 cells to diamides $5 \mathrm{a}$ and $5 \mathrm{~h}$ led to a significant increase in the percentage of cells at Sub- $\mathrm{G}_{1}$ by 14and 15.5-folds, respectively, with concurrent significant arrest in the $\mathrm{G}_{2}-\mathrm{M}$ phase by 2.2- and 2.5-folds, respectively, compared to control, which could be considered as significant remarks for sulfonamides $5 \mathrm{a}$ and $5 \mathrm{~h}$ to provoke apoptosis in renal UO-31 cells. 
Annexin V-FITC Apoptosis Assay

To explore whether the anti-proliferative activity of diamide-based sulfonamides $5 \mathrm{a}$ and $5 \mathrm{~h}$ is consistent with the induction of apoptosis within the UO-31 cancer cells, Annexin V-FITC/propidium iodide (AV/PI) dual staining assay was performed by flow cytometry (Figure 4).

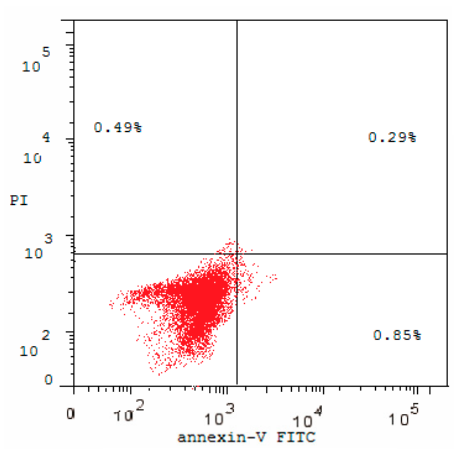

Control

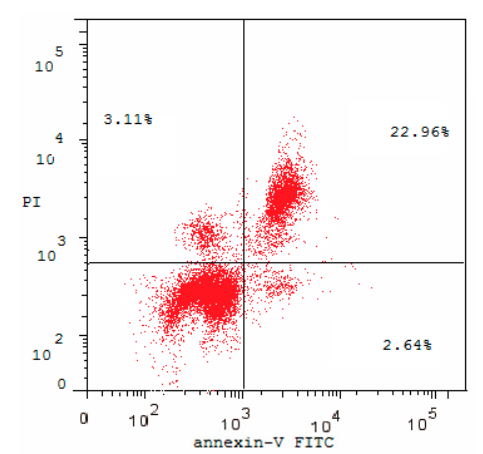

$5 a$

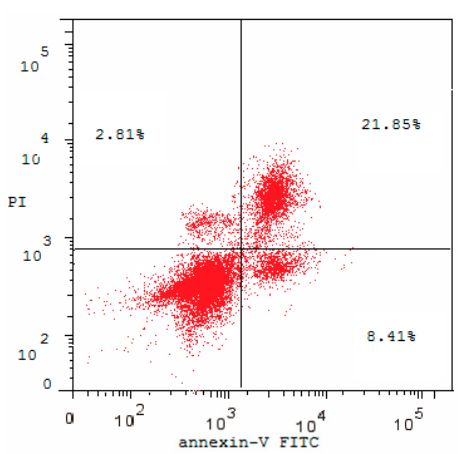

$5 \mathrm{~h}$

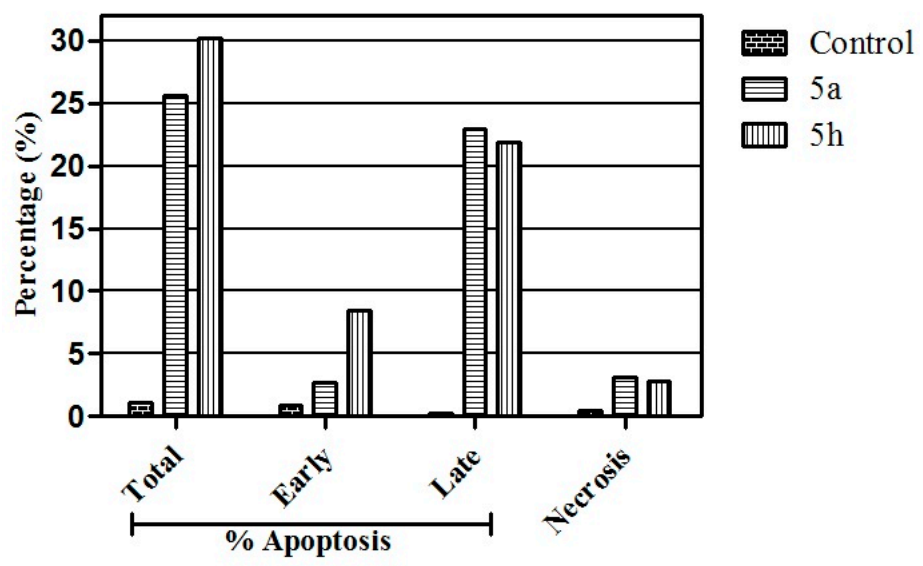

Figure 4. Effect of diamide-based benzenesulfonamides 5a and $5 \mathrm{~h}$ on the percentage of annexin V-FITC-positive staining in UO-31 cells. The experiments were done in triplicates. The four quadrants identified as: LL, viable; LR, early apoptotic; UR, late apoptotic; UL, necrotic.

The results suggested that diamides $5 \mathrm{a}$ and $5 \mathrm{~h}$ could induce the apoptosis of UO-31 cells as evidenced by the significant increase in the percent of annexin V-FITC-positive apoptotic cells, including both the early (from $0.85 \%$ to $2.64 \%$ for $5 \mathrm{a}$, and from $0.95 \%$ to $8.41 \%$ for $5 \mathrm{~h}$ ) and late apoptotic (from $0.29 \%$ to $22.96 \%$ for 5 a, and from $0.29 \%$ to $21.85 \%$ for $5 \mathrm{~h}$ ) phases (UR + LR), which represents about 22.5- and 26.5-folds total increase as compared with the control.

\subsection{Molecular Modelling Study}

To provide insights into the binding interactions of the reported diamide-based benzenesulfonamides within hCA isozymes II and IX (PDB 5LJT [22] and 5FL4 [23]), docking and MM-GBSA-based refinements were performed. As expected, in all docking solutions found for compounds $5 \mathrm{a}-\mathrm{h}$, the benzenesulfonamide is placed deeply into the active site region of both isozymes, with the zinc-binding group coordinating to the metal ion through its negatively charged nitrogen. Moreover, the sulfonamide moiety engages two $\mathrm{H}$-bonds: the $\mathrm{NH}^{-}$group acts as donor, while the $\mathrm{S}=\mathrm{O}$ as acceptor with T199 OG1 atom and backbone $\mathrm{NH}$ respectively. The phenyl ring accommodates in the hydrophobic region lined by V121, V143 and L198.

In hCA II, the carbonyl group of the amidic linker of derivatives $5 \mathrm{a}-\mathrm{h}$ accepts a $\mathrm{H}$-bond by the HE-Q92, orienting the arylidene moiety in a cleft defined by N67, Q92, I91 and F131 residues, where 
compounds $5 \mathrm{a}-\mathrm{g}$ can engage $\pi-\pi$ interactions. The benzoyl moiety accessed in a lipophilic pocket situated just above the H64, whose imidazole $\mathrm{NH}$ acts as H-bond donor towards the oxygen atom of the carbonyl group (Figure 5A).

A

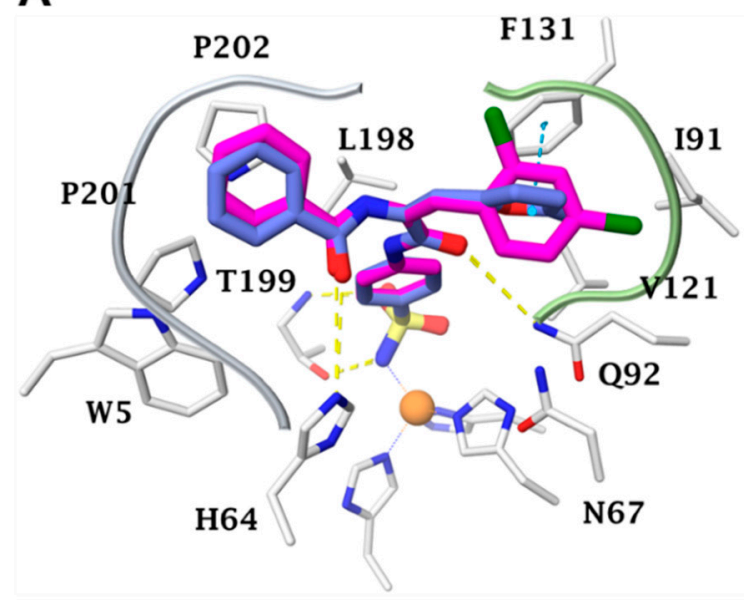

B

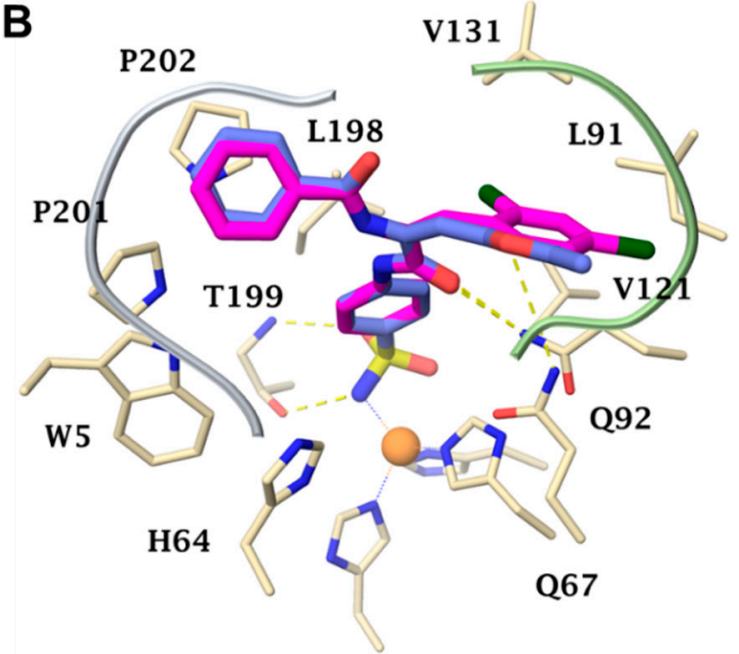

Figure 5. Docking of 5b (purple) and 5h (violet) in hCA II (A) and in hCA IX (B) active sites.

As for hCA II, a similar set of interactions is also found for the hCA IX isoform. However, because of the substitution V131/F131 (hCA XI/II), the arylidene moiety accommodates in a wider cavity, more suited to the size of the group. As a result, the latter makes more effective interactions with the receptor counterpart, thus probably contributing to the 1.5 to 14 -fold hCA IX/II selectivity of compounds $5 \mathrm{a}-\mathrm{h}$. The methylfuryl derivative $5 \mathrm{~h}$ further shows an additional $\mathrm{H}$-bond between the heterocyclic oxygen and Q67 HE atom (Figure 5B).

\section{Materials and Methods}

\subsection{Chemistry}

\subsubsection{General}

Melting points were measured with a Stuart melting point apparatus and were uncorrected. The NMR spectra were recorded by Varian Gemini-400BB $400 \mathrm{MHz}$ FT-NMR spectrometers (Varian Inc., Palo Alto, CA). ${ }^{1} \mathrm{H}$ and ${ }^{13} \mathrm{C}$ spectra were run at 400 and $100 \mathrm{MHz}$, respectively, in deuterated dimethylsulphoxide (DMSO- $d_{6}$ ). All coupling constant $(J)$ values are given in hertz. Chemical shifts $\left(\delta_{\mathrm{C}}\right)$ are reported relative to DMSO- $d_{6}$ as internal standards. The abbreviations used are as follows: $\mathrm{s}$, singlet; d, doublet; $\mathrm{m}$, multiplet. IR spectra were recorded with a Bruker FT-IR spectrophotometer. Reaction courses and product mixtures were routinely monitored by thin layer chromatography (TLC) on silica gel precoated $\mathrm{F}_{254}$ Merck plates. Unless otherwise noted, all solvents and reagents were commercially available and were used without further purification. Azlactones $3 \mathrm{a}-\mathrm{g}$ were previously reported [24,25].

\subsubsection{General Procedure for Preparation of Target Diamide-Based Benzenesulfonamides 5a-h}

A mixture of $p$-aminobenzenesulfonamide $4(0.17 \mathrm{~g}, 1 \mathrm{mmol})$, sodium acetate $(0.08 \mathrm{~g}, 1 \mathrm{mmol})$ and the appropriate azlactone derivative $3 \mathrm{a}-\mathrm{h}(1 \mathrm{mmol})$ in glacial acetic acid was heated under reflux for $4 \mathrm{~h}$. The solid product obtained upon cooling was filtered off and recrystallized from acetone to produce the corresponding benzenesulfonamides $5 a-h$, with $80-93 \%$ yield. 
N-(1-(4-Chlorophenyl)-3-oxo-3-((4-sulfamoylphenyl)amino)prop-1-en-2-yl)benzamide (5a)

White crystal (yield 93\%), m.p. 255-258 ${ }^{\circ} \mathrm{C}$; IR $\left(\mathrm{KBr}, v \mathrm{~cm}^{-1}\right)$ : 3311, $3255\left(\mathrm{NH}, \mathrm{NH}_{2}\right), 1704,1639$ $(2 \mathrm{C}=\mathrm{O})$ and 1316, $1156\left(\mathrm{SO}_{2}\right) ;{ }^{1} \mathrm{H}$ NMR (DMSO-d6) $\delta p p m: 7.10$ (s, $1 \mathrm{H}$, olefinic), $7.24\left(\mathrm{~s}, 2 \mathrm{H}, \mathrm{NH}_{2} \mathrm{D}_{2} \mathrm{O}\right.$ exchangeable), $7.44\left(\mathrm{~d}, 2 \mathrm{H}, J=8.4 \mathrm{~Hz}, \mathrm{H}-3, \mathrm{H}-5\right.$ of $\left.\mathrm{C}_{6} \mathrm{H}_{5}\right), 7.49\left(\mathrm{t}, 1 \mathrm{H}, J=8.0 \mathrm{~Hz}, \mathrm{H}-4\right.$ of $\left.\mathrm{C}_{6} \mathrm{H}_{5}\right), 7.51(\mathrm{~d}$, $2 \mathrm{H}, J=8.0 \mathrm{~Hz}, \mathrm{H}-3, \mathrm{H}-5$ of $\left.4-\mathrm{Cl}-\mathrm{C}_{6} \mathrm{H}_{4}\right), 7.62\left(\mathrm{~d}, 2 \mathrm{H}, J=8.4 \mathrm{~Hz}, \mathrm{H}-2, \mathrm{H}-6\right.$ of $\left.\mathrm{C}_{6} \mathrm{H}_{5}\right), 7.74(\mathrm{~d}, 2 \mathrm{H}, J=8.8$ $\mathrm{Hz}, \mathrm{H}-2, \mathrm{H}-6$ of sulfonamide), $7.85(\mathrm{~d}, 2 \mathrm{H}, J=8.8 \mathrm{~Hz}, \mathrm{H}-3, \mathrm{H}-5$ of sulfonamide), $7.98(\mathrm{~d}, 2 \mathrm{H}, J=8.0 \mathrm{~Hz}$, $\mathrm{H}-2, \mathrm{H}-6$ of $\left.4-\mathrm{Cl}_{-} \mathrm{C}_{6} \mathrm{H}_{4}\right), 10.15$ (s, $1 \mathrm{H}, \mathrm{NH} \mathrm{D} \mathrm{D}_{2} \mathrm{O}$ exchangeable), 10.53 (s, $1 \mathrm{H}, \mathrm{NH} \mathrm{D} \mathrm{D}_{2} \mathrm{O}$ exchangeable); ${ }^{13} \mathrm{C}$ NMR (DMSO- $d_{6}$ ) $\delta$ ppm: 119.93, 126.92, 127.37, 128.39, 128.88, 129.08, 131.60, 131.93, 132.39, 133.57, 133.60, 133.66, 138.97, 142.70, 165.13, 166.48; HRMS (ESI) for $\mathrm{C}_{22} \mathrm{H}_{19} \mathrm{ClN}_{3} \mathrm{O}_{4} \mathrm{~S}$, calcd 456.07793, found $456.07800[\mathrm{M}+\mathrm{H}]^{+}$; Anal. calcd. for $\mathrm{C}_{22} \mathrm{H}_{18} \mathrm{ClN}_{3} \mathrm{O}_{4} \mathrm{~S}$ (455.91): C, 57.96; H, 3.98; N, 9.22. Found C, 58.17; $\mathrm{H}, 3.89 ; \mathrm{N}, 9.11$.

N-(1-(2,4-Dichlorophenyl)-3-oxo-3-((4-sulfamoylphenyl)amino)prop-1-en-2-yl)benzamide (5b)

White crystal (yield 91\%), m.p. $265-267^{\circ} \mathrm{C}$; IR $\left(\mathrm{KBr}, v \mathrm{~cm}^{-1}\right)$ : 3303, $3249\left(\mathrm{NH}, \mathrm{NH}_{2}\right), 1711,1629$ $(2 \mathrm{C}=\mathrm{O})$ and 1310, $1153\left(\mathrm{SO}_{2}\right) ;{ }^{1} \mathrm{H}$ NMR (DMSO-d6) $\delta$ ppm: 7.04 (s, $1 \mathrm{H}$, olefinic), $7.25\left(\mathrm{~s}, 2 \mathrm{H}, \mathrm{NH}_{2} \mathrm{D}_{2} \mathrm{O}\right.$ exchangeable), $7.40\left(\mathrm{dd}, 1 \mathrm{H}, J=2.0 \mathrm{~Hz}, J=8.4 \mathrm{~Hz}, \mathrm{H}-5\right.$ of $2,4\left(\mathrm{Cl}_{2}{ }_{2}-\mathrm{C}_{6} \mathrm{H}_{3}\right), 7.46(\mathrm{t}, 1 \mathrm{H}, J=8.0 \mathrm{~Hz}, \mathrm{H}-4$ of $\left.\mathrm{C}_{6} \mathrm{H}_{5}\right), 7.48\left(\mathrm{~d}, 1 \mathrm{H}, J=8.0 \mathrm{~Hz}, \mathrm{H}-6\right.$ of $\left.2,4(\mathrm{Cl})_{2}-\mathrm{C}_{6} \mathrm{H}_{3}\right), 7.55\left(\mathrm{~d}, 2 \mathrm{H}, J=8.0 \mathrm{~Hz}, \mathrm{H}-3, \mathrm{H}-5\right.$ of $\left.\mathrm{C}_{6} \mathrm{H}_{5}\right), 7.71(\mathrm{~s}$, $1 \mathrm{H}, \mathrm{H}-3$ of $\left.2,4(\mathrm{Cl})_{2}-\mathrm{C}_{6} \mathrm{H}_{3}\right), 7.75(\mathrm{~d}, 2 \mathrm{H}, J=8.8 \mathrm{~Hz}, \mathrm{H}-2, \mathrm{H}-6$ of sulfonamide), $7.86(\mathrm{~d}, 2 \mathrm{H}, J=8.8 \mathrm{~Hz}, \mathrm{H}-3$, $\mathrm{H}-5$ of sulfonamide), $7.91\left(\mathrm{~d}, 2 \mathrm{H}, J=7.6 \mathrm{~Hz}, \mathrm{H}-2, \mathrm{H}-6\right.$ of $\left.\mathrm{C}_{6} \mathrm{H}_{5}\right), 10.14\left(\mathrm{~s}, 1 \mathrm{H}, \mathrm{NH} \mathrm{D} \mathrm{D}_{2} \mathrm{O}\right.$ exchangeable), 10.57 (s, $1 \mathrm{H}, \mathrm{NH} \mathrm{D} 2 \mathrm{O}$ exchangeable); ${ }^{13} \mathrm{C}$ NMR (DMSO- $d_{6}$ ) $\delta$ ppm: 120.08, 122.58, 126.95, 127.98, 128.41, 128.83, 129.50, 131.53, 132.19, 132.45, 133.54, 133.95, 134.06, 134.49, 139.18, 142.44, 164.52, 166.46; Anal. calcd. for $\mathrm{C}_{22} \mathrm{H}_{17} \mathrm{Cl}_{2} \mathrm{~N}_{3} \mathrm{O}_{4} \mathrm{~S}$ (490.36): C, 53.89; $\mathrm{H}, 3.49 ; \mathrm{N}, 8.57$. Found C, 53.65; H, 3.48; N, 8.68.

N-(1-(4-Bromophenyl)-3-oxo-3-((4-sulfamoylphenyl)amino)prop-1-en-2-yl)benzamide (5c)

Yellow powder (yield $80 \%$ ), m.p. $210-212{ }^{\circ} \mathrm{C}$; IR $\left(\mathrm{KBr}, v \mathrm{~cm}^{-1}\right)$ : 3312, $3250\left(\mathrm{NH}, \mathrm{NH}_{2}\right), 1704,1636$ $(2 \mathrm{C}=\mathrm{O})$ and 1316, $1156\left(\mathrm{SO}_{2}\right) ;{ }^{1} \mathrm{H}$ NMR (DMSO-d6) $\delta p p m: 7.07\left(\mathrm{~s}, 1 \mathrm{H}\right.$, olefinic), $7.29\left(\mathrm{~s}, 2 \mathrm{H}, \mathrm{NH}_{2} \mathrm{D}_{2} \mathrm{O}\right.$ exchangeable), $7.42\left(\mathrm{t}, 1 \mathrm{H}, J=8.0 \mathrm{~Hz}, \mathrm{H}-4\right.$ of $\left.\mathrm{C}_{6} \mathrm{H}_{5}\right), 7.45-7.52\left(\mathrm{~m}, 2 \mathrm{H}, \mathrm{H}-3, \mathrm{H}-5\right.$ of $\left.\mathrm{C}_{6} \mathrm{H}_{5}\right), 7.52-7.58(\mathrm{~m}$, $2 \mathrm{H}, \mathrm{H}-3, \mathrm{H}-5$ of $\left.4-\mathrm{Br}^{-} \mathrm{C}_{6} \mathrm{H}_{4}\right), 7.70,8.28\left(\mathrm{~d}, 2 \mathrm{H}, \mathrm{H}-2, \mathrm{H}-6\right.$ of $\left.\mathrm{C}_{6} \mathrm{H}_{5}\right), 7.74(\mathrm{~d}, 2 \mathrm{H}, \mathrm{H}-2, \mathrm{H}-6$ of sulfonamide), $7.85\left(\mathrm{~d}, 2 \mathrm{H}, \mathrm{H}-3, \mathrm{H}-5\right.$ of sulfonamide), $7.98\left(\mathrm{~d}, 2 \mathrm{H}, \mathrm{J}=8.0 \mathrm{~Hz}, \mathrm{H}-2, \mathrm{H}-6\right.$ of $\left.4-\mathrm{Br}^{-} \mathrm{C}_{6} \mathrm{H}_{4}\right), 10.61(\mathrm{~s}, 2 \mathrm{H}, \mathrm{NH}$ $\mathrm{D}_{2} \mathrm{O}$ exchangeable); ${ }^{13} \mathrm{C}$ NMR (DMSO- $d_{6}$ ) $\delta$ ppm: 119.89, 122.28, 124.82, 126.91, 126.99, 127.07, 127.14, $127.51,128.23,128.40,128.65,128.79,128.84,128.93,129.02,129.46,130.49,131.65,131.83,131.98,132.20$, 132.22, 132.32, 132.43, 133.69, 133.77, 133.98, 134.52, 137.59, 138.90, 139.18, 142.76, 144.17, 161.30, 165.24, 166.52, 169.69; Anal. calcd. for $\mathrm{C}_{22} \mathrm{H}_{18} \mathrm{BrN}_{3} \mathrm{O}_{4} \mathrm{~S}$ (500.37): C, 52.81; H, 3.63; N, 8.40. Found C, 60.02; $\mathrm{H}$, $3.60 ; \mathrm{N}, 8.31$.

N-(3-Oxo-3-((4-sulfamoylphenyl)amino)-1-(p-tolyl)prop-1-en-2-yl)benzamide (5d)

Yellow powder (yield $87 \%$ ), m.p. $255-258^{\circ} \mathrm{C}$; IR $\left(\mathrm{KBr}, v \mathrm{~cm}^{-1}\right)$ : 3313, $3251\left(\mathrm{NH}, \mathrm{NH}_{2}\right), 1701,1639$ $(2 \mathrm{C}=\mathrm{O})$ and 1319, $1157\left(\mathrm{SO}_{2}\right) ;{ }^{1} \mathrm{H}$ NMR (DMSO-d6) $\delta$ ppm: 2.28, $2.36\left(2 \mathrm{~s}, \mathrm{H}, \mathrm{CH}_{3}\right), 7.13,7.24(2 \mathrm{~s}, 1 \mathrm{H}$, olefinic), 7.27 (s, $2 \mathrm{H}, \mathrm{NH}_{2} \mathrm{D}_{2} \mathrm{O}$ exchangeable), 7.18, $8.00\left(2 \mathrm{~d}, 2 \mathrm{H}, J=7.6, \mathrm{H}-3, \mathrm{H}-5\right.$ of $\left.\mathrm{C}_{6} \mathrm{H}_{5}\right), 7.31,8.23$ $\left(2 \mathrm{~d}, 2 \mathrm{H}, J=8.4 \mathrm{~Hz}, \mathrm{H}-2, \mathrm{H}-6\right.$ of $\left.\mathrm{C}_{6} \mathrm{H}_{5}\right), 7.39-7.51\left(\mathrm{~m}, 4 \mathrm{H}, \mathrm{Ar}-\mathrm{H}\right.$ of $\left.4-\mathrm{CH}_{3}-\mathrm{C}_{6} \mathrm{H}_{4}\right), 7.49,7.53(2 \mathrm{t}, 1 \mathrm{H}, J=8.0$ $\mathrm{Hz}, \mathrm{H}-4$ of $\mathrm{C}_{6} \mathrm{H}_{5}$ ), 7.74 (d, 2H, H-2, H-6 of sulfonamide), 7.85 (d, 2H, H-3, H-5 of sulfonamide), 10.09 (s, $1 \mathrm{H}, \mathrm{NH} \mathrm{D} \mathrm{D}_{2} \mathrm{O}$ exchangeable), 10.45 (s, $1 \mathrm{H}, \mathrm{NH} \mathrm{D}_{2} \mathrm{O}$ exchangeable); ${ }^{13} \mathrm{C}$ NMR (DMSO- $\left.d_{6}\right) \delta$ ppm: 21.38, $21.75\left(\mathrm{CH}_{3}\right), 119.95,126.88,127.10,128.34,128.60,128.85,128.96,129.01,129.38,129.63,130.01,130.07$, 130.36, 131.72, 131.77, 131.97, 132.28, 132.92, 133.85, 137.74, 137.93, 138.86, 139.02, 141.51, 142.77, 144.04, 160.23, 165.31, 166.44, 169.74; HRMS (ESI) for $\mathrm{C}_{23} \mathrm{H}_{22} \mathrm{~N}_{3} \mathrm{O}_{4} \mathrm{~S}$, calcd 436.13255, found $436.13251[\mathrm{M}+\mathrm{H}]^{+}$; Anal. calcd. for $\mathrm{C}_{23} \mathrm{H}_{21} \mathrm{~N}_{3} \mathrm{O}_{4} \mathrm{~S}$ (435.50): $\mathrm{C}, 63.43 ; \mathrm{H}, 4.86 ; \mathrm{N}$, 9.65. Found $\mathrm{C}, 63.57 ; \mathrm{H}, 4.83 ; \mathrm{N}, 9.58$. 
N-(1-(4-Methoxyphenyl)-3-oxo-3-((4-sulfamoylphenyl)amino)prop-1-en-2-yl)benzamide (5e)

Yellow powder (yield 88\%), m.p. $265-268^{\circ} \mathrm{C}$; IR $\left(\mathrm{KBr}, v \mathrm{~cm}^{-1}\right)$ : 3309, $3247\left(\mathrm{NH}, \mathrm{NH}_{2}\right), 1703,1634$ $(2 \mathrm{C}=\mathrm{O})$ and $1314,1154\left(\mathrm{SO}_{2}\right) ;{ }^{1} \mathrm{H}$ NMR (DMSO-d6) $\delta p p m: 3.74,3.83\left(2 \mathrm{~s}, 3 \mathrm{H}, \mathrm{OCH}_{3}\right), 6.93,8.33(2 \mathrm{~d}$, $2 \mathrm{H}, J=8.8 \mathrm{~Hz}, \mathrm{H}-3, \mathrm{H}-5$ of $\left.\mathrm{C}_{6} \mathrm{H}_{5}\right), 7.07,8.04\left(2 \mathrm{~d}, 2 \mathrm{H}, J=8.4 \mathrm{~Hz}, \mathrm{H}-2, \mathrm{H}-6\right.$ of $\left.\mathrm{C}_{6} \mathrm{H}_{5}\right), 7.18,7.32(2 \mathrm{~s}, 1 \mathrm{H}$, olefinic), 7.39-7.45 (m, 4H, H-3, H-5 and H-2, H-6 of 4- $\left.\mathrm{OCH}_{3}-\mathrm{C}_{6} \mathrm{H}_{4}\right), 7.47(\mathrm{t}, 1 \mathrm{H}, J=8.0 \mathrm{~Hz}, \mathrm{H}-4$ of $\left.\mathrm{C}_{6} \mathrm{H}_{5}\right), 7.49$ (s, $2 \mathrm{H}, \mathrm{NH}_{2} \mathrm{D}_{2} \mathrm{O}$ exchangeable), 7.54, $7.72(2 \mathrm{~d}, 2 \mathrm{H}, J=8.8 \mathrm{~Hz}, \mathrm{H}-2, \mathrm{H}-6$ of sulfonamide), 7.58, $7.85(2 \mathrm{~d}, 2 \mathrm{H}, J=8.8 \mathrm{~Hz}, \mathrm{H}-3, \mathrm{H}-5$ of sulfonamide), 10.95 (s, 2H, NH D $2 \mathrm{O}$ exchangeable); Anal. calcd. for $\mathrm{C}_{23} \mathrm{H}_{21} \mathrm{~N}_{3} \mathrm{O}_{5} \mathrm{~S}$ (451.50): $\mathrm{C}, 61.19 ; \mathrm{H}, 4.69 ; \mathrm{N}, 9.31$. Found $\mathrm{C}, 60.88 ; \mathrm{H}, 4.65 ; \mathrm{N}, 9.30$.

N-(1-(2,4-Dimethoxyphenyl)-3-oxo-3-((4-sulfamoylphenyl)amino)prop-1-en-2-yl)benzamide (5f)

Yellow powder (yield 85\%), m.p. $245-250^{\circ} \mathrm{C}$; IR $\left(\mathrm{KBr}, v \mathrm{~cm}^{-1}\right)$ : 3410, $3294\left(\mathrm{NH}, \mathrm{NH}_{2}\right), 1701,1639$ $(2 \mathrm{C}=\mathrm{O})$ and 1369, $1161\left(\mathrm{SO}_{2}\right) ;{ }^{1} \mathrm{H}$ NMR (DMSO- $\left.d 6\right) \delta p p m: 3.75\left(\mathrm{~s}, 3 \mathrm{H}, \mathrm{OCH}_{3}\right), 3.81\left(\mathrm{~s}, 3 \mathrm{H}, \mathrm{OCH}_{3}\right)$, $6.65\left(\mathrm{~s}, 1 \mathrm{H}, \mathrm{H}-3\right.$ of $\left.\left(\mathrm{OCH}_{3}\right)_{2}-\mathrm{C}_{6} \mathrm{H}_{3}\right), 7.42\left(\mathrm{dd}, 2 \mathrm{H}, \mathrm{J}=2.4 \mathrm{~Hz}, \mathrm{~J}=9.2 \mathrm{~Hz}, \mathrm{H}-5, \mathrm{H}-6\right.$ of $\left.\left(\mathrm{OCH}_{3}\right)_{2}-\mathrm{C}_{6} \mathrm{H}_{3}\right)$, 7.41-7.47 (m, $4 \mathrm{H}, \mathrm{H}-3, \mathrm{H}-5$ of $\mathrm{C}_{6} \mathrm{H}_{4}$ and $\mathrm{NH}_{2} \mathrm{D}_{2} \mathrm{O}$ exchangeable), $7.49\left(\mathrm{t}, 1 \mathrm{H}, J=8.0 \mathrm{~Hz}, \mathrm{H}-4\right.$ of $\left.\mathrm{C}_{6} \mathrm{H}_{5}\right)$, 7.55 (s, $1 \mathrm{H}$, olefinic), $7.63\left(\mathrm{~d}, 2 \mathrm{H}, \mathrm{H}-2, \mathrm{H}-6\right.$ of $\left.\mathrm{C}_{6} \mathrm{H}_{5}\right), 7.72(\mathrm{~d}, 2 \mathrm{H}, J=8.8 \mathrm{~Hz}, \mathrm{H}-2, \mathrm{H}-6$ of sulfonamide), $7.85\left(\mathrm{~d}, 2 \mathrm{H}, J=8.8 \mathrm{~Hz}, \mathrm{H}-3, \mathrm{H}-5\right.$ of sulfonamide), $10.16\left(\mathrm{~s}, 1 \mathrm{H}, \mathrm{NH} \mathrm{D} \mathrm{D}_{2} \mathrm{O}\right.$ exchangeable), $10.65(\mathrm{~s}, 1 \mathrm{H}$, $\mathrm{NH} \mathrm{D} \mathrm{D}_{2} \mathrm{O}$ exchangeable); Anal. calcd. for $\mathrm{C}_{24} \mathrm{H}_{23} \mathrm{~N}_{3} \mathrm{O}_{6} \mathrm{~S}$ (481.52): $\mathrm{C}, 59.87 ; \mathrm{H}, 4.81 ; \mathrm{N}, 8.73$. Found $\mathrm{C}$, $60.09 ; \mathrm{H}, 4.83 ; \mathrm{N}, 8.67$.

N-(1-(3,4-Dimethoxyphenyl)-3-oxo-3-((4-sulfamoylphenyl)amino)prop-1-en-2-yl)benzamide (5g)

Yellow powder (yield 90\%), m.p. $250-253^{\circ} \mathrm{C}$; IR $\left(\mathrm{KBr}, v \mathrm{~cm}^{-1}\right)$ : 3413, $3292\left(\mathrm{NH}, \mathrm{NH}_{2}\right), 1701,1639$ $(2 \mathrm{C}=\mathrm{O})$ and 1369, $1161\left(\mathrm{SO}_{2}\right) ;{ }^{1} \mathrm{H}$ NMR (DMSO- $\left.d 6\right) \delta p p m: 3.75\left(\mathrm{~s}, 3 \mathrm{H}, \mathrm{OCH}_{3}\right), 3.78\left(\mathrm{~s}, 3 \mathrm{H}, \mathrm{OCH}_{3}\right)$, 6.97, $8.20\left(\mathrm{~d}, 2 \mathrm{H}, \mathrm{H}-3, \mathrm{H}-5\right.$ of $\left.\mathrm{C}_{6} \mathrm{H}_{5}\right), 7.21-7.29\left(\mathrm{~m}, 4 \mathrm{H}, \mathrm{H}-5, \mathrm{H}-6\right.$ of $\left(\mathrm{OCH}_{3}\right)_{2}-\mathrm{C}_{6} \mathrm{H}_{3}$ and $\mathrm{NH} 2 \mathrm{D}_{2} \mathrm{O}$ exchangeable), 7.43-7.46 (m, $2 \mathrm{H}, \mathrm{H}-3$ of $\left(\mathrm{OCH}_{3}\right)_{2}-\mathrm{C}_{6} \mathrm{H}_{3}$ and olefinic), 7.48, $7.51(\mathrm{t}, 1 \mathrm{H}, J=8.0 \mathrm{~Hz}, \mathrm{H}-4$ of $\left.\mathrm{C}_{6} \mathrm{H}_{5}\right), 7.57,8.04\left(\mathrm{~d}, 2 \mathrm{H}, J=8.4 \mathrm{~Hz}, \mathrm{H}-2, \mathrm{H}-6\right.$ of $\left.\mathrm{C}_{6} \mathrm{H}_{5}\right), 7.74(\mathrm{~d}, 2 \mathrm{H}, J=8.8 \mathrm{~Hz}, \mathrm{H}-2, \mathrm{H}-6$ of sulfonamide), $7.86\left(\mathrm{~d}, 2 \mathrm{H}, J=8.8 \mathrm{~Hz}, \mathrm{H}-3, \mathrm{H}-5\right.$ of sulfonamide), 10.07 (s, $1 \mathrm{H}, \mathrm{NH} \mathrm{D} \mathrm{D}_{2} \mathrm{O}$ exchangeable), $10.36(\mathrm{~s}, 1 \mathrm{H}, \mathrm{NH}$ $\mathrm{D}_{2} \mathrm{O}$ exchangeable); ${ }^{13} \mathrm{C}$ NMR (DMSO- $\left.d_{6}\right) \delta p p m: 55.52\left(\mathrm{OCH}_{3}\right), 55.95\left(\mathrm{OCH}_{3}\right), 112.00,112.95,120.07$, 124.11, 126.86, 127.02, 127.11, 128.31, 128.57, 128.75, 128.82, 129.04, 129.22, 130.30, 132.31, 133.83, 138.84, 142.77, 148.73, 150.03, 165.28, 166.37; Anal. calcd. for $\mathrm{C}_{24} \mathrm{H}_{23} \mathrm{~N}_{3} \mathrm{O}_{6} \mathrm{~S}$ (481.52): C, 59.87; $\mathrm{H}, 4.81 ; \mathrm{N}, 8.73$. Found C, 60.13; H, 4.77; N, 8.64 .

N-(1-(5-Methylfuran-2-yl)-3-oxo-3-((4-sulfamoylphenyl)amino)prop-1-en-2-yl)benzamide (5h)

Orange powder (yield 87\%), m.p. $240-243^{\circ} \mathrm{C}$; IR $\left(\mathrm{KBr}, v \mathrm{~cm}^{-1}\right)$ : 3413, $3295\left(\mathrm{NH}, \mathrm{NH}_{2}\right), 1706,1636$ $(2 \mathrm{C}=\mathrm{O})$ and 1366, $1160\left(\mathrm{SO}_{2}\right) ;{ }^{1} \mathrm{H}$ NMR (DMSO-d6) $\delta$ ppm: 2.20, $2.40\left(2 \mathrm{~s}, 1 \mathrm{H}, \mathrm{CH}_{3}\right), 6.23(\mathrm{~d}, 1 \mathrm{H}, \mathrm{H}-4$ furan), 6.46, $8.13\left(2 \mathrm{~d}, 2 \mathrm{H}, \mathrm{H}-3, \mathrm{H}-5\right.$ of $\left.\mathrm{C}_{6} \mathrm{H}_{5}\right), 6.69$ (d, 1H, H-3 furan), 7.05, 7.12 (2s, $1 \mathrm{H}$, olefinic), 7.23 (s, $2 \mathrm{H}, \mathrm{NH}_{2} \mathrm{D}_{2} \mathrm{O}$ exchangeable), 7.33-7.47 (m, $2 \mathrm{H}, \mathrm{H}-2, \mathrm{H}-6$ of $\left.\mathrm{C}_{6} \mathrm{H}_{5}\right), 7.48\left(\mathrm{t}, 1 \mathrm{H}, J=8.0 \mathrm{~Hz}, \mathrm{H}-4\right.$ of $\left.\mathrm{C}_{6} \mathrm{H}_{5}\right)$, $7.74\left(\mathrm{~d}, 2 \mathrm{H}, \mathrm{H}-2, \mathrm{H}-6\right.$ of sulfonamide), $7.83-7.86\left(\mathrm{~m}, 2 \mathrm{H}, \mathrm{H}-3, \mathrm{H}-5\right.$ of sulfonamide), 9.85 (s, $1 \mathrm{H}, \mathrm{NH} \mathrm{D}_{2} \mathrm{O}$ exchangeable), $10.23\left(\mathrm{~s}, 1 \mathrm{H}, \mathrm{NH} \mathrm{D} \mathrm{D}_{2} \mathrm{O}\right.$ exchangeable); ${ }^{13} \mathrm{C}$ NMR (DMSO-d $\left.d_{6}\right) \delta p p m: 13.89\left(\mathrm{CH}_{3}\right), 14.30$ $\left(\mathrm{CH}_{3}\right), 109.31,111.59,115.59,116.81,118.58,120.17,121.62,122.08,122.46,126.32,126.83,127.06,127.10$, $128.34,128.71,128.93,128.99,129.02,129.31,131.42,131.83,132.13,134.60,135.05,137.78,138.91,142.61$, 144.01, 148.66, 149.53, 149.74, 154.60, 156.33, 157.81, 158.18, 158.88, 164.41, 166.35, 166.43, 169.07; Anal. calcd. for $\mathrm{C}_{21} \mathrm{H}_{19} \mathrm{~N}_{3} \mathrm{O}_{5} \mathrm{~S}$ (425.46): C, 59.28; $\mathrm{H}, 4.50 ; \mathrm{N}$, 9.88. Found C, 59.15; H, 4.46; N, 9.97.

\subsection{Biological Evaluation}

\subsubsection{CA Inhibitory Assay}

An Applied Photophysics stopped-flow instrument was used for assaying the $\mathrm{CA}$ catalysed $\mathrm{CO}_{2}$ hydration activity, as reported earlier [17]. The inhibition constants were obtained by non-linear least-squares methods using PRISM 3 and the Cheng-Prusoff equation as reported earlier, and represent 
the mean from at least three different determinations. The four tested CA isofoms were recombinant ones obtained in-house as reported earlier [26-29].

\subsubsection{Anticancer Activity towards 60 Cancer Cell Lines (NCI, Bethesda, MD, USA)}

This assay was carried out according to the protocol of the Drug Evaluation Branch, NCI, Bethesda [30-32]. The cell growth and cell viability were evaluated using the sulforhodamine B (SRB) [26] colorimetric assay, as reported earlier [33,34].

\subsubsection{Antiproliferative Activity towards Renal Cancer UO-31 Cell Line}

Renal cancer UO-31 cell line was obtained from American Type Culture Collection (ATCC). UO-31 cells were seeded into 96-well plates at $1.8 \times 10^{4} /$ well. Cells were grown in DMEM, and supplemented with $10 \%$ heat-inactivated fetal bovine serum, $1 \%$ L-glutamine $(2.5 \mathrm{mM})$, HEPES buffer $(10 \mathrm{mM})$, $50 \mu \mathrm{g} / \mathrm{mL}$ gentamycin. All cells were maintained at $37^{\circ} \mathrm{C}$ in a humidified atmosphere with $5 \% \mathrm{CO}_{2}$. Cytotoxic activity of diamide-based benzenesulfonamides $5 \mathrm{a}, 5 \mathrm{~b}$ and $5 \mathrm{~h}$ was evaluated following the the protocol of MTT colorimetric assay, as reported previously $[35,36]$.

\subsubsection{Cell Cycle Analysis}

Renal cancer UO-31 cells were treated with diamide-based benzenesulfonamide $5 \mathrm{~h}$ at its $\mathrm{IC}_{50}$ concentration $\left(\mathrm{IC}_{50}=4.89 \pm 0.22 \mu \mathrm{M}\right)$ for $24 \mathrm{~h}$, and then cells were washed with ice-cold phosphate buffered saline (PBS). Then, the treated cells were collected by centrifugation, fixed in ice-cold $70 \%$ $(v / v)$ ethanol, washed with PBS, re-suspended with RNase $(100 \mu \mathrm{g} / \mathrm{mL})$, stained with PI $(40 \mu \mathrm{g} / \mathrm{mL})$, and analyzed by flow cytometry using FACS Calibur (Becton Dickinson, BD, USA). The cell cycle distributions were calculated utilizing CellQuest software 5.1 (Becton Dickinson) [37,38].

\subsubsection{Annexin V-FITC Apoptosis Assay}

Assay of the phosphatidylserine externalization was carried out using Annexin V-FITC/PI apoptosis detection kit (BD Biosciences, San Jose, CA, USA) following the manufacturer's instructions, as reported previously $[39,40]$.

\subsubsection{Molecular Docking Simulations}

Preparation of the crystal structure of both hCAII (PDB 5LJT [32]) and hCAIX (PDB 5FL4 [33]) was performed using the Protein Preparation Wizard tool implemented in Maestro-Schrödinger suite, assigning bond orders, adding hydrogens, deleting water molecules, and optimizing H-bonding networks [41]. Energy minimization protocol with a root mean square deviation (RMSD) value of 0.30 was applied using an Optimized Potentials for Liquid Simulation (OPLS3) force field. For the simulations with sulfonate derivatives, 5JLT and 5FL4 were prepared adding the zinc-bound water molecule as fourth ligand of the metal tetrahedral coordination sphere. 3D ligand structures were prepared by Maestro [43a] and evaluated for their ionization states at $\mathrm{pH} 7.4 \pm 0.5$ with Epik [41b]. OPLS3 force field in Macromodel [41e] was used for energy minimization for a maximum number of 2500 conjugate gradient iteration and setting a convergence criterion of $0.05 \mathrm{kcal}$ mol- $1 \AA$ - 1 . The docking grid was centered on the center of mass of the co-crystallized ligands, and was Glide used with default settings. Ligands were docked with the standard precision mode (SP) of Glide [41f] and the best 5 poses of each molecule retained as output. The best pose for each compound, evaluated in terms of coordination, hydrogen bond interactions and hydrophobic contacts, was refined by Prime [41d] with a VSGB solvatation model considering the target flexible within $3 \AA$ around the ligand [42-44].

\section{Conclusions}

In summary, this study reports the synthesis of novel series of diamide-based benzenesulfonamides 5a-h. The prepared diamides were examined as inhibitors of CA isoforms hCA I, II, IX and XII, using 
a stopped-flow $\mathrm{CO}_{2}$ hydrase assay. All the tested isoforms were inhibited by the diamide-based benzenesulfonamides $5 \mathrm{a}-\mathrm{h}$ herein reported in variable degrees; hCA I was inhibited with $K_{\mathrm{I}} \mathrm{s}$ in the range of 796.1-8175nM, hCA II in the range of 68.3-448 nM; hCA IX in the range of 8.3-123.3 nM, whereas hCA XII in the range of 9.8-134.5 nM. Notably, diamides $5 \mathrm{a}$ and $5 \mathrm{~h}$ stood out as a single-digit nanomolar hCA IX inhibitors with $K_{\mathrm{I}}$ values $=8.8$ and $8.3 \mathrm{nM}$, respectively, which are about three times more potent than the standard drug AAZ $\left(K_{\mathrm{I}}=25 \mathrm{nM}\right)$. All the examined diamides $5 \mathrm{a}-\mathrm{h}$ displayed interesting selectivity towards hCA IX over hCA I with SIs spanning in the range 12.8-985. Also, they possessed good hCA IX/II SIs in the range 3.6-13.8, apart from diamides $5 \mathrm{~d}$ and $5 \mathrm{e}$ which exhibited modest selectivity ( $\mathrm{SI}=1.4$ and 1.5 , respectively). Interestingly, bioisosteric replacement of the benzylidene moiety with the hetero 2-furylidene moiety, compound $5 \mathrm{~h}$, achieved the best IX/I and IX/II selectivity herein reported with SIs of 985 and 13.8, respectively. Molecular docking simulations of the prepared diamides in CA IX active site unveiled the ability of $5 \mathrm{~h}$ to establish an additional $\mathrm{H}$-bond between the heterocyclic oxygen and HE/Gln67. Moreover, benzenesulfonamides $5 \mathrm{a}, 5 \mathrm{~b}$ and $5 \mathrm{~h}$ were selected to be in vitro evaluated for their antitumor activity against renal cancer UO-31 cell line. Notably, $5 \mathrm{~h}$ was the most potent derivative with about 1.5 -fold more enhanced activity $\left(\mathrm{IC}_{50}=\right.$ $4.89 \pm 0.22 \mu \mathrm{M})$ than the reference drug Staurosporine $\left(\mathrm{IC}_{50}=7.25 \pm 0.43 \mu \mathrm{M}\right)$. Furthermore, $5 \mathrm{a}$ and $5 \mathrm{~h}$ were able to induce apoptosis in UO-31 cells as evidenced by the significant increase in the percent of annexinV-FITC positive apoptotic cells by 22.5 - and 26.5 -folds, respectively, as compared with the control.

Supplementary Materials: Supplementary materials can be found at http://www.mdpi.com/1422-0067/20/10/ 2484/s1.

Author Contributions: Conceptualization, W.M.E.; Data curation, A.N. and S.B.; Formal analysis, G.S.H.; Funding acquisition, S.T.A.-R. and A.A.A.; Methodology, Mohamed A.A., W.M.E., A.N., S.B., S.T.A.-R., G.S.H., A.B., A.A. and P.G.; Project administration, W.M.E.; Resources, S.T.A.-R. and H.M.A.; Supervision, C.T.S.; Writing-original draft, M.A.A., G.S.H., A.B., A.A.A., H.M.A., A.A. and P.G.; Writing-review \& editing, W.M.E., A.N. and C.T.S.

Funding: The authors would like to extend their sincere appreciation to the Deanship of Scientific Research at King Saud University for its funding of this research through the Research Group Project no. RG-1439-65.

Conflicts of Interest: The authors declare no conflict of interest.

\section{References}

1. Alterio, V.; Di Fiore, A.; D'Ambrosio, K.; Supuran, C.T.; De Simone, G. Multiple Binding Modes of Inhibitors to Carbonic Anhydrases: How to Design Specific Drugs Targeting 15 Different Isoforms? Chem. Rev. 2012, 112, 4421-4468. [CrossRef] [PubMed]

2. Ozensoy Guler, O.; Capasso, C.; Supuran, C.T. A magnificent enzyme superfamily: Carbonic anhydrases, their purification and characterization. J. Enzym. Inhib. Med. Chem. 2016, 31, 689-694. [CrossRef] [PubMed]

3. Vullo, D.; Durante, M.; Di Leva, F.S.; Cosconati, S.; Masini, E.; Scozzafava, A.; Novellino, E.; Supuran, C.T.; Carta, F. Monothiocarbamates Strongly Inhibit Carbonic Anhydrases in Vitro and Possess Intraocular Pressure Lowering Activity in an Animal Model of Glaucoma. J. Med. Chem. 2016, 59, 5857-5867. [CrossRef] [PubMed]

4. Supuran, C.T. Carbonic Anhydrase Inhibition and the Management of Hypoxic Tumors. Metabolites 2017, 7, 48. [CrossRef] [PubMed]

5. Gieling, R.G.; Babur, M.; Mamnani, L.; Burrows, N.; Telfer, B.A.; Carta, F.; Winum, J.-Y.; Scozzafava, A.; Supuran, C.T.; Williams, K.J. Antimetastatic Effect of Sulfamate Carbonic Anhydrase IX Inhibitors in Breast Carcinoma Xenografts. J. Med. Chem. 2012, 55, 5591-5600. [CrossRef]

6. Pacchiano, F.; Carta, F.; McDonald, P.C.; Lou, Y.; Vullo, D.; Scozzafava, A.; Dedhar, S.; Supuran, C.T. Ureido-Substituted Benzenesulfonamides Potently Inhibit Carbonic Anhydrase IX and Show Antimetastatic Activity in a Model of Breast Cancer Metastasis. J. Med. Chem. 2011, 54, 1896-1902. [CrossRef]

7. Abo-Ashour, M.F.; Eldehna, W.M.; Nocentini, A.; Ibrahim, H.S.; Bua, S.; Abdel-Aziz, H.A.; Abou-Seri, S.M.; Supuran, C.T. Novel synthesized SLC-0111 thiazole and thiadiazole analogues: Determination of their carbonic anhydrase inhibitory activity and molecular modeling studies. Bioorg. Chem. 2019, 87, 794-802. [CrossRef] 
8. Eldehna, W.M.; Abo-Ashour, M.F.; Berrino, E.; Vullo, D.; Ghabbour, H.A.; Al-Rashood, S.T.; Hassan, G.S.; Alkahtani, H.M.; Almehizia, A.A.; Alharbi, A.; et al. SLC-0111 enaminone analogs, 3/4-(3-aryl-3-oxopropenyl) aminobenzenesulfonamides, as novel selective subnanomolar inhibitors of the tumor-associated carbonic anhydrase isoform IX. Bioorganic Chem. 2019, 83, 549-558. [CrossRef]

9. Ibrahim, H.S.; Allam, H.A.; Mahmoud, W.R.; Bonardi, A.; Nocentini, A.; Gratteri, P.; Ibrahim, E.S.; Abdel-Aziz, H.A.; Supuran, C.T. Dual-tail arylsulfone-based benzenesulfonamides differently match the hydrophobic and hydrophilic halves of human carbonic anhydrases active sites: Selective inhibitors for the tumor-associated hCA IX isoform. Eur. J. Med. Chem. 2018, 152, 1-9. [CrossRef]

10. Eldehna, W.M.; Fares, M.; Ceruso, M.; Ghabbour, H.A.; Abou-Seri, S.M.; Abdel-Aziz, H.A.; El Ella, D.A.A.; Supuran, C.T. Amido/ureidosubstituted benzenesulfonamides-isatin conjugates as low nanomolar/subnanomolar inhibitors of the tumor-associated carbonic anhydrase isoform XII. Eur. J. Med. Chem. 2016, 110, 259-266. [CrossRef]

11. Eldehna, W.M.; Abo-Ashour, M.F.; Nocentini, A.; El-Haggar, R.S.; Bua, S.; Bonardi, A.; Al-Rashood, S.T.; Hassan, G.S.; Gratteri, P.; Abdel-Aziz, H.A.; et al. Enhancement of the tail hydrophobic interactions within the carbonic anhydrase IX active site via structural extension: Design and synthesis of novel N-substituted isatins-SLC-0111 hybrids as carbonic anhydrase inhibitors and antitumor agents. Eur. J. Med. Chem. 2019, 162, 147-160. [CrossRef] [PubMed]

12. Eldehna, W.M.; Nocentini, A.; Al-Rashood, S.T.; Hassan, G.S.; Alkahtani, H.M.; Almehizia, A.A.; Reda, A.M.; Abdel-Aziz, H.A.; Supuran, C.T. Tumor-associated carbonic anhydrase isoform IX and XII inhibitory properties of certain isatin-bearing sulfonamides endowed with in vitro anticancer activity towards colon cancer, Bioorg. Med. Chem. 2018, 81, 425-432.

13. Eldehna, W.M.; Abo-Ashour, M.F.; Nocentini, A.; Gratteri, P.; Eissa, I.H.; Fares, M.; Ismael, O.E.; Ghabbour, H.A.; Elaasser, M.M.; Abdel-Aziz, H.A.; et al. Novel 4/3-((4-oxo-5-(2-oxoindolin-3-ylidene) thiazolidin-2-ylidene)amino) benzenesulfonamides: Synthesis, carbonic anhydrase inhibitory activity, anticancer activity and molecular modelling studies. Eur. J. Med. Chem. 2017, 139, 250-262. [CrossRef] [PubMed]

14. Jun, E.E. Ueber die Condensation der Hippursäure mit Phtalsäureanhydrid und mit Benzaldehyd. Justus Liebigs Ann. Chem. 1893, 275, 1-8. [CrossRef]

15. Acheson, R.M.; Booth, D.A.; Brettle, R.; Harris, A.M. 694. The synthesis of some acylglycines and related oxazolones. J. Chem. Soc. 1960, 3457. [CrossRef]

16. Cleary, T.; Rawalpally, T.; Kennedy, N.; Chavez, F. Catalyzing the Erlenmeyer Plöchl reaction: Organic bases versus sodium acetate. Tetrahedron Lett. 2010, 51, 1533-1536. [CrossRef]

17. Khalifah, R.G. The carbon dioxide hydration activity of carbonic anhydrase. I. Stop-flow kinetic studies on the native human isoenzymes B and C. J. Boil. Chem. 1971, 246, 2561-2573.

18. Skehan, P.; Scudiero, D.; Vistica, D.; Bokesch, H.; Kenney, S.; Storeng, R.; Monks, A.; McMahon, J.; Warren, J.T.; Boyd, M.R. New Colorimetric Cytotoxicity Assay for Anticancer-Drug Screening. J. Natl. Cancer Inst. 1990, 82, 1107-1112. [CrossRef]

19. Eldehna, W.M.; El Kerdawy, A.M.; Al-Ansary, G.H.; Al-Rashood, S.T.; Ali, M.M.; Mahmoud, A.E. Type IIA-Type IIB protein tyrosine kinase inhibitors hybridization as an efficient approach for potent multikinase inhibitor development: Design, synthesis, anti-proliferative activity, multikinase inhibitory activity and molecular modeling of novel indolinone-based ureides and amides. Eur. J. Med. Chem. 2019, 163, 37-53.

20. Eldehna, W.M.; Fares, M.; Ibrahim, H.S.; Alsherbiny, M.A.; Aly, M.H.; Ghabbour, H.A.; Abdel-Aziz, H.A.; Eynde, J.J.V.; Mayence, A. Synthesis and Cytotoxic Activity of Biphenylurea Derivatives Containing Indolin-2-one Moieties. Molecules 2016, 21, 762. [CrossRef]

21. Mosmann, T. Rapid colorimetric assay for cellular growth and survival: Application to proliferation and cytotoxicity assays. J. Immunol. Methods 1983, 65, 55-63. [CrossRef]

22. Nocentini, A.; Ferraroni, M.; Carta, F.; Ceruso, M.; Gratteri, P.; Lanzi, C.; Masini, E.; Supuran, C.T. Benzenesulfonamides Incorporating Flexible Triazole Moieties Are Highly Effective Carbonic Anhydrase Inhibitors: Synthesis and Kinetic, Crystallographic, Computational, and Intraocular Pressure Lowering Investigations. J. Med. Chem. 2016, 59, 10692-10704. [CrossRef]

23. Leitans, J.; Kazaks, A.; Balode, A.; Ivanova, J.; Zalubovskis, R.; Supuran, C.T.; Tars, K. Efficient Expression and Crystallization System of Cancer-Associated Carbonic Anhydrase Isoform IX. J. Med. Chem. 2015, 58, 9004-9009. [CrossRef] 
24. Parveen, M.; Ali, A.; Ahmed, S.; Malla, A.M.; Alam, M.; Pereira Silva, P.S.; Silva, M.R.; Lee, D.U. Synthesis, bioassay, crystal structure and ab initio studies of Erlenmeyer azlactones, Spectrochim. Acta A Mol. Biomol. Spectrosc. 2013, 104, 538-545. [CrossRef]

25. Conway, P.A.; Devine, K.; Paradisi, F. A simple and efficient method for the synthesis of Erlenmeyer azlactones. Tetrahedron 2009, 65, 2935-2938. [CrossRef]

26. Alafeefy, A.M.; Ahmad, R.; Abdulla, M.; Eldehna, W.M.; Al-Tamimi, A.M.S.; Abdel-Aziz, H.A.; Al-Obaid, O.; Carta, F.; Al-Kahtani, A.A.; Supuran, C.T. Development of certain new 2-substituted-quinazolin-4-ylaminobenzenesulfonamide as potential antitumor agents. Eur. J. Med. Chem. 2016, 109, 247-253. [CrossRef]

27. Fares, M.; Eladwy, R.A.; Nocentini, A.; El Hadi, S.R.A.; Ghabbour, H.A.; Abdel-Megeed, A.; Eldehna, W.M.; Abdel-Aziz, H.A.; Supuran, C.T. Synthesis of bulky-tailed sulfonamides incorporating pyrido [2, 3-d][1,2,4] triazolo [4, 3-a] pyrimidin-1 (5H)-yl) moieties and evaluation of their carbonic anhydrases I, II, IV and IX inhibitory effects. Bioorg. Med. Chem. 2017, 25, 2210-2217. [CrossRef]

28. Abo-Ashour, M.F.; Eldehna, W.M.; Nocentini, A.; Ibrahim, H.S.; Bua, S.; Abou-Seri, S.M.; Supuran, C.T. Novel hydrazido benzenesulfonamides-isatin conjugates: Synthesis, carbonic anhydrase inhibitory activity and molecular modeling studies. Eur. J. Med. Chem. 2018, 157, 28-36. [CrossRef]

29. Melis, C.; Meleddu, R.; Angeli, A.; Distinto, S.; Bianco, G.; Capasso, C.; Cottiglia, F.; Angius, R.; Supuran, C.T.; Maccioni, E. Isatin: A privileged scaffold for the design of carbonic anhydrase inhibitors. J. Enzym. Inhib. Med. Chem. 2017, 32, 68-73. [CrossRef]

30. Monks, A.; Scudiero, D.; Skehan, P.; Shoemaker, R.; Paull, K.; Vistica, D.; Hose, C.; Langley, J.; Cronise, P.; Vaigro-Wolff, A.; et al. Feasibility of a High-Flux Anticancer Drug Screen Using a Diverse Panel of Cultured Human Tumor Cell Lines. J. Natl. Cancer Inst. 1991, 83, 757-766. [CrossRef]

31. Beverly, A.T. Cancer Drug Discovery and Development. In Anticancer Drug Development Guide: Preclinical Screening, Clinical Trials and Approval, 2nd ed.; Humana Press: Totowa, NJ, USA, 2014; pp. 41-62, (Chapter 1).

32. Boyd, M.R.; Paull, K.D. Some practical considerations and applications of the National Cancer Institute in vitro anticancer drug discovery screen. Drug Dev. Res. 1995, 34, 91-109.

33. Eldehna, W.M.; Hassan, G.S.; Al-Rashood, S.T.; Al-Warhi, T.; Altyar, A.E.; Alkahtani, H.M.; Almehizia, A.A.; Abdel-Aziz, H.A. Synthesis and in vitro anticancer activity of certain novel 1-(2-methyl-6-arylpyridin-3-yl)3-phenylureas as apoptosis-inducing agents. J. Enzym. Inhib. Med. Chem. 2019, 34, 322-332. [CrossRef] [PubMed]

34. Abo-Ashour, M.F.; Eldehna, W.M.; George, R.F.; Abdel-Aziz, M.M.; Elaasser, M.M.; Gawad, N.M.A.; Gupta, A.; Bhakta, S.; Abou-Seri, S.M. Novel indole-thiazolidinone conjugates: Design, synthesis and whole-cell phenotypic evaluation as a novel class of antimicrobial agents. Eur. J. Med. Chem. 2018, 160, 49-60. [CrossRef] [PubMed]

35. Almahli, H.; Hadchity, E.; Jaballah, M.Y.; Daher, R.; Ghabbour, H.A.; Kabil, M.M.; Al-Shakliah, N.S.; Eldehna, W.M. Development of novel synthesized phthalazinone-based PARP-1 inhibitors with apoptosis inducing mechanism in lung cancer. Bioorg. Chem. 2018, 77, 443-456.

36. Ismail, R.S.; Abou-Seri, S.M.; Eldehna, W.M.; Ismail, N.S.; Elgazwi, S.M.; Ghabbour, H.A.; Ahmed, M.S.; Halaweish, F.T.; El Ella, D.A.A. Novel series of 6-(2-substitutedacetamido)-4-anilinoquinazolines as EGFR-ERK signal transduction inhibitors in MCF-7 breast cancer cells. Eur. J. Med. Chem. 2018, 155, 782-796. [CrossRef] [PubMed]

37. Sabt, A.; Abdelhafez, O.M.; El-Haggar, R.S.; Madkour, H.M.F.; Eldehna, W.M.; El-Khrisy, E.E.-D.A.M.; Abdel-Rahman, M.A.; Rashed, L.A. Novel coumarin-6-sulfonamides as apoptotic anti-proliferative agents: Synthesis, in vitro biological evaluation, and QSAR studies. J. Enzym. Inhib. Med. Chem. 2018, 33, 1095-1107. [CrossRef] [PubMed]

38. Eldehna, W.M.; El-Naggar, D.H.; Hamed, A.R.; Ibrahim, H.S.; Ghabbour, H.A.; Abdel-Aziz, H.A.; Ghabbour, H.A. Abdel-Aziz One-pot three-component synthesis of novel spirooxindoles with potential cytotoxic activity against triple-negative breast cancer MDAMB-231 cells. J. Enzym. Inhib. Med. Chem. 2018, 33, 309-318. [CrossRef]

39. Eldehna, W.M.; Almahli, H.; Al-Ansary, G.H.; Ghabbour, H.A.; Aly, M.H.; Ismael, O.E.; Al-Dhfyan, A.; Abdel-Aziz, H.A. Synthesis and in vitro anti-proliferative activity of some novel isatins conjugated with quinazoline/phthalazine hydrazines against triple-negative breast cancer MDA-MB-231 cells as apoptosis-inducing agents. J. Enzym. Inhib. Med. Chem. 2017, 32, 600-613. [CrossRef] 
40. Eldehna, W.M.; Abo-Ashour, M.F.; Ibrahim, H.S.; Al-Ansary, G.H.; Ghabbour, H.A.; Elaasser, M.M.; Ahmed, H.Y.A.; Safwat, N.A. Novel [(3-indolylmethylene)hydrazono]indolin-2-ones as apoptotic anti-proliferative agents: Design, synthesis and in vitro biological evaluation. J. Enzym. Inhib. Med. Chem. 2018, 33, 686-700. [CrossRef]

41. Schrödinger Suite Release 2018-2: (a) Maestrov.11.6; (b) Epik, v.4.4; (c) Impact, v.7.9; (d) Prime, v.5.2; (e) Macromodel v.12.0. (f) Glide, v.7.9; Schrödinger, L.L.C.: New York, NY, USA, 2018.

42. Nocentini, A.; Carta, F.; Tanc, M.; Selleri, S.; Supuran, C.T.; Bazzicalupi, C.; Gratteri, P. Deciphering the Mechanism of Human Carbonic Anhydrases Inhibition with Sulfocoumarins: Computational and Experimental Studies. Chemistry 2018, 24, 7840-7844. [CrossRef]

43. Nocentini, A.; Gratteri, P.; Supuran, C.T. Phosphorus versus Sulfur: Discovery of Benzenephosphonamidates as Versatile Sulfonamide-Mimic Chemotypes Acting as Carbonic Anhydrase Inhibitors. Chemistry 2019, 25, 1188-1192. [CrossRef]

44. Nocentini, A.; Bonardi, A.; Gratteri, P.; Cerra, B.; Gioiello, A.; Supuran, C.T. Steroids interfere with human carbonic anhydrase activity by using alternative binding mechanisms. J. Enzym. Inhib. Med. Chem. 2018, 33, 1453-1459. [CrossRef]

(C) 2019 by the authors. Licensee MDPI, Basel, Switzerland. This article is an open access article distributed under the terms and conditions of the Creative Commons Attribution (CC BY) license (http://creativecommons.org/licenses/by/4.0/). 